\title{
LEARNING TO LIVE WITH THE DILEMMA \\ OF DIFFERENCE: BILINGUAL AND SPECIAL EDUCATION
}

\author{
Martha Minow* \\ I \\ INTRODUCTION
}

Bilingual education and special education initially appear to be different solutions to different problems. Bilingual education offers instruction to children whose primary language is not English; special education offers instruction to children with physical or emotional handicaps. What the two programs share seems quite superficial: they attend to the needs and interests of some identifiable subset of the student population, both have sparked political controversy, and sometimes they overlap or deal with the same children. ${ }^{1}$ At this superficial level, comparing the two programs hardly seems likely to reveal anything that is not already apparent about each one.

This article suggests, however, that a comparison of the programs yields important insights into why each one has been controversial and what may be at stake in the construction and implementation of the programs. In so doing, this article argues that the two programs actually encounter the same problem, which can be cast as the question: how can schools deal with children defined as "different" without stigmatizing them on that basis? For a glimpse of the shared problem, consider this curiosity: during the past few decades, educational policymakers switched allegiance to bilingual programs, pulling students at least part-time from the mainstream classroom, while at the same time educators have sponsored special education programs integrating exceptional students into the mainstream classroom. This changingof-the-guard on integration suggests an initial version of the dilemma encountered by bilingual and special education. Are the stigma and unequal treatment encountered by minority groups better remedied by separation or by integration of such groups with others? Either remedy risks reinforcing the stigma associated with assigned difference by either ignoring it or focusing on it. This double-edged risk is the "difference dilemma."

Copyright (C) 1985 by Law and Contemporary Problems

* Assistant Professor, Harvard University Law School. The author would like to thank Katharine Bartlett, William Clune, Clare Dalton, Christopher Edley, Jr., Richard Fallon, Gunter Frankenberg, Gerald Frug, Louis Kaplow, David Kennedy, Duncan Kennedy, Frank Michelman, Kathleen Sullivan, and Judith Wegner for their comments on an earlier version of this article.

1. See generally L. Baca \& H. Cervantes, The Bilingual Special Education Interface (1984) (examining programs treating children who qualify for special education and also for whom English is a second language). 
One seeming way out of the dilemma would be to focus on the means to achieve chosen ends. On examination, however, this route yields no escape from the difference dilemma. Constructing measures to achieve the ends of schooling is always a problematic enterprise. Unintended consequences and counterproductive results often occur, and a particular implementation problem arises in response to the desired goal of preventing the stigmatization of children who are identified as different from the rest of the students. In a powerful sense, the dilemma of difference reappears as decisionmakers consider whether the school should be structured to replicate the larger community in terms of population mix and cultural mores, or instead should create an enclave away from that larger community. Which approach, for example, would better prepare a student to deal with the adult community? Which approach would better prepare a minority group to overcome discrimination in the larger community? Are the ends of schooling better attained by designing a microcosm of the world inside the school to give students practice with it, or by designing different environments tailored to support students and accommodate their differences? This design problem arises as much for those who wish to use the schools to preserve existing social arrangements as for those who wish to use schools for social change, or for some combination of these goals. Whatever position on change and stability educators and parents select, whether the school is more likely to achieve that position by replicating the larger community or by serving as an enclave away from it is still open for debate. ${ }^{2}$

Another seeming way out of the dilemma would address techniques for constraining the power of the school which may otherwise stigmatize some children. Yet this approach also fails to escape the difference dilemma. As programs mandated by law are subject to litigation, bilingual and special education expose to scrutiny the nature of the school power deployed to deal with children who are considered different. Should the school personnel and programs assume a relationship to students modeled on a parent-child relationship or modeled on a state-citizen relationship? Different procedures, methods, and directions in school programming follow from this choice, and different legal frameworks for school activities would also result. There is no clear choice between parental and state models of school power given the public school's status as both protector and promoter of youth and as a staterun institution wielding state power. In the context of the dilemma of difference, addressing the legal shape of school power hardly solves the problem of limiting state stigmatization of students; rather, it recasts the dilemma as a choice between sharply contrasting but equally plausible procedural models. An examination of bilingual education and special education exposes the difference dilemma and its recurrence in decisions over the means and ends of schooling and the legal conceptions of school power.

2. This debate includes the issue: can the school be treated solely as a means, preparing students for the world beyond, or must it also be understood as itself a community, whether constructed to resemble the larger community or assuming a structure and climate of its own? 
The difference dilemma and its reappearance in debates over means and ends and over constraining school power should not be surprising; these issues appear in varied forms in the history of American education. Indeed, the problems' very conventional quality-conventionally understood to exist and to resist resolution-may dull our awareness of them and nonetheless cabin debates over bilingual and special education. By highlighting the dilemma of difference and its reappearance in other forms, this article does not claim to offer a solution. Instead, it suggests that heightened awareness may permit a new stance toward the dilemma and new approaches toward living with it. ${ }^{3}$ Thus, this article is written with the commitment that self-conscious reflection about the ways we think about our problems may offer new possibilities in continuing efforts to deal with those problems. ${ }^{4}$ Budgetary and bureaucratic problems will not disappear in the face of new conceptual understandings; however, new attitudes and strategies for dealing with these very problems could emerge. In short, we cannot change our world simply by thinking about it differently, nor can we change it unless we think differently enough to see where we are, and, with this sight, act differently.

This article first describes the difference dilemma and its expression within the histories, laws, and programs of bilingual and special education. The reoccurrence of the difference dilemma in the problems of designing educational programs and constraining school power is examined next. Finally, the article offers an alternative approach to the difference dilemma and some examples of problem-solving using this approach.

\section{The Difference Dilemma}

This nation is committed to both pluralism and equality, yet it also bears a history of prejudice against people whom the dominant group calls different. Indeed, differences in race, gender, and ethnicity have spelled determinate positions on its social hierarchy. But nonrecognition of difference leaves in place a faulty neutrality, constructed so as to advance the dominant group and hinder those who are different. No wonder people caught in the dilemma

3. Cf. A. Wheelis, How People Change 17, 100 (1973) (describing psychotherapy: therapeutic insight does not produce change but is instrumental to it; suffering does not disappear without a change in underlying conflict which connects to changes in how one lives, feels, and reacts).

4. See S. Cavell, Pursuits of Happiness: The Hollywood Comedy of Remarriage 10-12 (1981) (describing philosophic commitment to "being guided by our experience but not dictated to by it" and "to educate your experience sufficiently that it is worthy of trust"); R. HowARD, THREE FaCES OF HeRmeneutics (1982) (philosophic traditions converging in study of knowledge and deliberate efforts to uncover role of the interpreter in interpretation); J. Sartre, SEarch for a METHOD 180 (H. Barnes trans. 2d ed. 1968) (freedom grasped as condition of human limits through self knowledge). See generally R. RiEfF, Fellow Teachers 23 (1973) (psychotherapy as "the social procedure of release from the authority of the past" but not rejecting the pre-existing world); P. RIEFF, Freud: The Mind of THE MORalist 65-101 (1975) (psychoanalytic uncovering of the hidden self bearing some relationship to freedom); Taylor, Interpretation and the Science of Man, in KNOWLEDGE AND Values in Social and Educational Research 153, 177-78 (E. Bredo \& W. Feinberg eds. 1982) (interpretation searches for subjective and shared meanings); A. WheELIs, supra note 3, at 113 (freedom depends on awareness but does not necessarily follow awareness). 
experience an impossibility of movement, for movement in any direction creates risks of recreating the dilemma.

Identification or acknowledgment of a trait of difference, associated by the dominant group with minority identity, risks recreating occasions for majority discrimination based on that trait. Nonidentification or nonacknowledgment, however, risks recreating occasions for discrimination based on majority practices, such as tests, norms, and judgments forged without regard for difference, or with regard solely for the perspective, needs, and interests of the dominant group. Because minority differences have been made to carry implications for a person's worth and status a minority member may be reluctant to expose or emphasize such difference. Yet nonexposure can subject the minority to evaluation by allegedly neutral criteria that in fact implement the majority values and view.

Similarly, separation or segregation of a minority group risks promoting distrust and misunderstandings based on group differences, and yet integration risks perpetuating chafing expressions of hostility between dominant and minority groups. Separation reinforces stigma and feelings of inferiority by the group historically encountering discrimination. Separation may also permit inequalities in resources as the majority allocates differentially to minority groups, sharing with itself its special access to resources and leaving the minority to struggle with less. Separation in the short run may promote the association of difference with inferiority by perpetuating group misunderstandings, minority feelings of inferiority, and majority feelings of superiority.

Yet integration also risks perpetuating hierarchy. It may deny minority members a safe place to develop themselves by isolating them as individuals amid the dominant group. By depriving minority group members of opportunities to develop group identity and strength, integration can imply or reinforce the inferiority of that minority identity. Patterns of difference are set in motion by inequalities of experience, of access to resources, and of selfesteem upon entry into the integrated setting, while the commitment to avoid reiterating difference in that setting can leave these patterns in place. A history of assigned difference and infirmity can be frozen, then, by a current commitment to stop assigning difference; both focusing on and ignoring difference risk recreating it. This is the dilemma of difference.

The dilemma is not à model nor a theoretical scheme, but a felt experience and pattern of social practice. This rather stark statement of the dilemma needs shading and context. The example of race and schooling helps ground the difference dilemma and helps locate it in a context more familiar to many than the subjects of bilingual and special education, to which the article then turns.

\section{A. The Example of Racial Desegregation}

The dilemma of difference should be familiar to students of the civil rights 
movement, for the efforts leading to and following Brown $v$. Board of Education ${ }^{5}$ demonstrate this dilemma-and the impossibility of avoiding its choice of undesirable alternatives. ${ }^{6}$ The situation of Linda Brown, who as a child had been involved in the landmark Brown case, offers a glimpse of the dilemma. Her childhood was indelibly marked by that historic case, itself a culmination of twenty years of legal struggle for the decision forbidding racial segregation in the schools. When she became a young mother, Linda Brown faced deteriorating public schools technically desegregated but effectively racially segregated, with more than half of the black grade-school children concentrated in six of the thirty-four elementary schools, four of which were at least 60 percent black. Both black and white parents, however, joined in opposition to city-wide busing to desegregate the schools. ${ }^{7}$

This development points to the historical movement after Brown in which groups working for desegregation chose community control as their watchword. ${ }^{8}$ Frustrated and disappointed with the tardy and controversial implementation of Brown, parents and civil rights leaders turned toward community control of basically segregated schools. Unraveling this historical journey reveals the persistent tension between the search for equality through integration and the search for equality through segregation. This tension is not the product of isolated historical actions but has appeared continuously in the search for equality.

The NAACP picked schools as the focal point of its attack on the Court's approval of Jim Crow laws in Plessy v. Ferguson. ${ }^{9}$ Indeed, the Court had supported the "separate but equal" principle upheld in Plessy in the context of railroads in part by reference to a Massachusetts state decision approving segregated schools. ${ }^{10}$ In Plessy the Court expressed awareness of the issue of how separation affected status and attributed inferiority. The Court reasoned,

[L]aws permitting, and even requiring, [racial] separation in places where [the races] are liable to be brought into contact do not necessarily imply the inferiority of either race to the other, and have been generally, if not universally, recognized as within the competency of the state legislatures in the exercise of their police power. ${ }^{11}$

So long as the accommodations provided were equal, continued the Court,

5. 347 U.S. 483 (1954).

6. The dilemma also occupies feminist discussions. See Eisenstein, Introduction to The Future of Difference at xv, xvii-xviii (H. Eisenstein \& A. Jardin eds. 1980); Jardin, Prelude: The Future of Difference, in The Future of Difference, supra, at xxv, xxvi. See generally The Future of Difference, supra.

7. See R. Kluger, Simple Justice $777-78$ (1976).

8. See generally M. Fantini, M. Gittell \& R. Magat, Community Control. and The Urban SCHOOL (1970) (failures of integration and compensatory education led to demands for community control by less powerful parent groups); D. Ravitch, The Great School Wars (1974); Comment, Alternative Schools for Minority Students: The Constitution, the Civil Rights Act and the Berkeley Experiment, 61 Calif. L. Rev. 858, 899 (1973) (arguing in favor of racially homogeneous community schools).

9. 163 U.S. 537 (1896).

10. See id. at 544 (citing Roberts v. City of Boston, 59 Mass. (5 Cush.) 198, 206 (1849)). The Massachusetts precedent had itself been superseded by state legislation requiring integrated schools just six years after the Roberts decision-long before Plessy.

11. Id. 
separation of the races itself carried no stigma. ${ }^{12}$

The NAACP in large measure took the Court at its word and challenged the equality of separate facilities rather than the principle of separate but equal. The litigation strategy conducted by the NAACP thus started with graduate level public universities and colleges, where separate facilities for blacks were either nonexistent or a sham. A string of victories required integration of law schools where no state supported legal education was available for blacks, ${ }^{13}$ integration of law schools where separate (but tangibly inferior) legal education was provided for blacks, ${ }^{14}$ and integration of graduate schools. ${ }^{15}$ Then the NAACP turned to the elementary schools with the same argument that the facilities for blacks are unequal. But the NAACP also hoped to assault at this point the "separate but equal" principle itself. The NAACP lawyers took advantage of evolving social science teachings which attacked traditional theories of racial victimization, and worked with social psychologist Kenneth Clark who developed studies of the low-self image of black children. ${ }^{16}$ Social science data became the basis for the controversial footnote 11 in Brown which was used to bolster the Court's reasoning that segregated education undermined the black child's self-esteem and motivation to learn, and its conclusion that, in the field of public education, "[s]eparate education facilities are inherently unequal." 17

The social science basis for this conclusion immediately triggered debate, ${ }^{18}$ and the desegregation remedies produced frustration and disappointment with the supposed link between integration and equality. White resistance in the form of violence, white flight, and continued stigmatization of blacks in integrated schools made segregation no longer the obvious target. Resenting their continued degradation and powerlessness, a new generation of black leaders started the Black Power movement and favored community control of local, segregated schools. They vocally rejected assimilation as a threat to black culture and black self-consciousness and sought to raise their group status through self-governance. ${ }^{19}$

Courts and scholars soon sensed these demands for community control and developed new schemes to remedy race discrimination with an emphasis on black empowerment and redistributed authority over schooling. The Atlanta Plan, often cited as a model, emphasized the hiring of blacks to fill administrative posts in the school system-including the job of the superin-

12. See id. at 551-52.

13. See, e.g., Missouri ex rel. Gaines v. Canada, 305 U.S. 337 (1938).

14. Sweatt v. Painter, 339 U.S. 629 (1950).

15. McLaurin v. Oklahoma State Regents for Higher Educ., 339 U.S. 637 (1950).

16. See R. KLUGER, supra note 7, at 315-45.

17. Brown-v. Board of Educ., 347 U.S. 483, 494-95 nn.10-11 (1954).

18. See, e.g., Cahn, Jurisprudence, 30 N.Y.U. L. Rev. 150, 153-54 (1955); Honnold, Book Review, 33 IND. L.J. 612, 614-15 (1958).

19. Ravitch, The Evolution of School Desegregation Policy, 1964-1979, in RaCe and Schooling IN THE City 9, 15 (1981); see also R. Blumberg, Civil Rights: The 1960's Freedom Struggle 117-37 (1984) (Black Power movement). 
tendent. ${ }^{20}$ Scholars like Derrick A. Bell, Jr. campaigned for judicial remedies addressing the quality of education rather than racial integration. ${ }^{21}$

Kenneth Clark reflected on these developments and warned that:

[Community control] may further isolate the poor and the minority groups from the majority society and bring the customary consequences of racial and class isolationeroded facilities, inadequate teaching and administrative staffs, and minimum resources. . . .

Community control, therefore, requires a commitment of the city as a whole, genuine delegation of power, and continued efforts to relate the community to the larger society. Perhaps paradoxically, the lower-status community will never have genuine power until its isolation is ended. ${ }^{22}$

The paradox, indeed, expresses the dilemma of difference: continued powerlessness for blacks could emerge from even self-chosen segregation, but powerlessness could also emerge from efforts to integrate with a larger community still assigning a lower status to blacks. Separation might permit the assertion of minority group identity and strength, but without acceptance and empowerment by the majority, the minority will continue to suffer from the associations between racial difference and social and political status.

This dilemma which arises in the treatment of racial difference was not, however, a new discovery in the post-Brown era. W.E.B. Dubois and Booker $T$. Washington had carried on a similar debate more than half a century before. In particular they debated the issue of whether reform efforts should seek to integrate blacks within the ideology and social patterns created by the dominant culture or should attempt to alter that culture by celebrating the separate heritage and culture of the minority group. ${ }^{23}$ Each position received periodic acclaim followed by blame as a cause of continuing racial oppression. Debate over these positions etched the shape of the difference dilemma. Continued attachment to a separate racial identity-complete with separate schools and cultural socialization-could perpetuate rather than alter the historic degradation of blacks; integration aimed at assimilation could do the same or even accentuate black student difference without equipping them with a supporting community backed by their own parents.

Assimilation continues to be criticized as either impossible or undesirable;

20. See Jackson, Urban School Desegregation from a Black Perspective, in RACE AND SCHOoling IN THE Ciтy 204, 209-11 (1981).

21. See Bell, Brown v. Board of Education and the Interest-Convergence Dilemma, 93 HARv. L. REv. 518 (1980); Bell, Waiting on the Promise of Brown, Law \& ConTEMP. Probs., Spring 1975, at 341; see also Bell, Serving Two Masters: Integration Ideals and Client Interests in School Desegregation Litigation, 85 YALE L.J. 470 (1976) (describing black opposition to school busing plans and criticizing public interest lawyers for failing to recognize minority group desires). See generally Hawley, The New.Mythology of School Desegregation, Law \& ConTEMP. ProbS., Autumn 1978, at 214 (criticizing scholarly disenchantment with desegregation).

22. Clark, Introduction to M. Fantini, M. Gittell \& R. Macat, supra note 8, at xi.

23. See M. Curti, The Social Ideas of American Educators 288-309 (1959) (comparing Washington and Dubois); R. Kluger, supra note 7, at 91-100 (same); see also W.E.B. DuboIS, ThE SOULS OF BLACK FOLK (1916) (describing richness of black heritage deserving preservation); $B$. Washington, Up From Slavery (1970) (describing his own education and conception of education for blacks). 
attributed differences continue to stigmatize. As one black parent told a white psychologist in the 1970's:

The goal, I think, is not that people have to get to the point of being colorblind. No one needs to tell me you're white, and no one needs to tell you I'm black. . . . The goal is simpler than that. You get to know our family, we get to know you and your family. That they aren't equal, well, that's what we're all going to have to live with. Maybe together we'll change it. ${ }^{24}$

Ignoring differences could reproduce them, even when well-intentioned people prescribe reforms. The prospect of learning new ways to live with the experience of difference may be what study of the dilemma offers.

\section{B. Bilingual Education and Special Education: Historical Preoccupations with Difference}

Historically, school programs for children who are not native English speakers have sometimes ignored their difference, but more recently they have emphasized it. Historically, school programs for children with handicaps have sometimes emphasized their differences, but more recently they have emphasized their similarities. Both types of programs continue to struggle with the dilemma of difference. A brief review of the histories of these programs, ${ }^{25}$ followed by an examination of their legal and programmatic structures, demonstrates this preoccupation.

1. Bilingual Education. Educators, lawyers, and historians frequently depict the history of bilingual education as a political struggle ultimately yielding recognition of native language as an important differentiating characteristic of students-a characteristic deserving accommodation by the public schools. This history begins with the presentation of this nation as a country peopled by immigrants who supplanted the language and culture of indigenous peoples. English became the dominant language in this country's public life. English is the language of the legislatures and courts, the marketplace, and the public schools. ${ }^{26}$

The supplanting of languages other than English in the schools did not, however, go uncontested. Subcommunities which maintained the language of their home country through local newspapers, cultural entertainment, and religious activities periodically pushed for recognition of their language and culture within the schools. Indeed, in some pockets, politically sophisticated immigrants successfully elected school boards which in turn implemented bilingual educational programs, preserving the ethnic language of the group while also instructing the children in English. ${ }^{27}$ Opposition to the use of for-

24. T. Cottle, Black Children, White Dreams 53 (1974).

25. This synthesis of the histories offered in textbooks and monographs does not attempt to uncover competing versions of the historical events that future scholarship may develop in response to shifting political attitudes about the programs.

26. See Edelman, Basic American, 6 NOLPE Sch. L.J. 83, 88 \& n.47 (1976) (majority of states have statutes requiring English to be primarily used in the public schools and allowing foreign languages to be used only to aid in the mastery of English) (listing statutes).

27. D. Tyack, The One Best System 106-09 (1974) (discussing German programs in Cincinnati 
eign languages in the schools, however, mounted; this sentiment motivated the enactment of statutes forbidding the teaching of any non-English language even in a private school to students below the eighth grade. One Court ruled that such a statute violated the Constitution's guarantee of liberty and due process. In Meyer $v$. Nebraska, even though the Court recognized the state's power to "foster a homogeneous people with American ideals, prepared readily to understand current discussions of civic matters," the Court concluded that the legislative means selected violated the Constitution. ${ }^{28}$ The decision in Meyer, then, became an important milestone in the nation's commitment to pluralism-but that decision did not place foreign languages on an equal footing with English. Nor did it entitle children to instruction in foreign language; it simply forbade rules proscribing such instruction. The case stands in the history of bilingual education as a reminder of longstanding local struggles over non-English instruction, marked by escalating opposition in the name of patriotism during wartime. ${ }^{29}$

Instruction in languages other than English became unpopular during and after the First World War, except as elective courses for students already proficient in English. ${ }^{30}$ Developments after World War II paved the way for the instruction in their mother tongue for children not proficient in English; mounting immigration, Cold War competition with the Soviet Union, and the civil rights movement all supplied bases for compensatory educational programs, including instruction for students whose native language was not English. ${ }^{31}$ Ethnic pride movements figured importantly in the call for combining language instruction with cultural awareness programs. The history of bilingual education usually concludes with a comparison of the experiences of immigrants who, earlier in the nation's history, had to or chose to abandon their ethnic heritage in contrast to contemporary groups who reject homogenization and nurture cultural difference.

This frequently depicted history of bilingual education is a story of the growing recognition of language and cultural differences and of the harm children experienced when such differences were not recognized. This story, then, manifests one half of the difference dilemma: nonacknowledgment of difference reiterates difference, given a social world making difference matter. Leonard Covello, the first New York City public school principal of Italian

and St. Louis, 1840-1890). See generally $\mathrm{H}$. Kloss, The American Bilingual Tradition (1977) (describing bilingual patterns in the 19th century).

28. 262 U.S. 390,402 (1923).

29. See, e.g., Wagner, The Historical Background of Bilingualism and Biculturalism in the United States, in The New Bilingualism: An American Dilemma 29, 42 (M. Ridge ed. 1981) ("We cannot tolerate any attempt to oppose or supplant the language and culture that has come down to us from the builders of this republic with the language and culture of any European country. The greatness of this nation depends on the swift assimilation of the aliens she welcomes to her shores.") (quoting Theodore Roosevelt).

30. T. Anderson \& M. Boyer, Bilingual Schooling in the United States 21-22 (2d ed. 1978); P. Cafferty \& C. Rivera-Martinez, The Politics of language: The Dilemma of Bilingual Education for Puerto Ricans 4, 14-15 (1981).

31. See Bilingual Education Act, Pub. L. No. 90-247, tit. VII, §§ 701-708, 81 Stat. 783 (1968) (current version at 20 U.S.C. $\$ \S 3221-3261$ (1982)). 
heritage, recalled his experience in the public schools at the turn of the century:

During this period the Italian language was completely ignored in the American schools. In fact, throughout my whole elementary school career, I do not recall one mention of Italy or the Italian language or what famous Italians had done in the world, with the possible exception of Columbus. . . . We soon got the idea that "Italian" meant something inferior, and a barrier was erected between children of Italian origin and their parents. This was the accepted process of Americanization. We were becoming Americans by learning how to be ashamed of our parents. ${ }^{32}$

Advocates of bilingual education link this shame about family, ethnicity, and ultimately self, to the poor academic achievement of many children for whom English is a second language. The advocates contend that it is worse than cruel, in fact it is devastating to a child's self-respect, when a child is forced to give up a family language while attending school. This denigrates not only the mother tongue but also the value system of the home culture. It is little wonder such children do poorly in school. Educating children in part in the language of their homes-at least until they have mastered it -is as important as learning English. This, it is argued, will create a spirit of selfrespect and self-confidence in students. ${ }^{33}$

Author Richard Rodriguez offered a different assessment of his parochial school education, where his native Spanish was not used or acknowledged:

Without question, it would have pleased me to hear my teachers address me in Spanish when I entered the classroom. I would have felt much less afraid. I would have trusted them and responded with ease. But I would have delayed-for how long postponed? - having to learn the language of public society. I would have evadedand for how long could I have afforded to delay?-learning the great lesson of school, that I had a public identity. And, [w] hat I needed to learn in school was that I had the right-and the obligation-to speak the public language of los gringos. ${ }^{34}$

Here then is the other side of the dilemma; acknowledgment of difference can create barriers to important aspects of the school experience and delay or derail successful entry into the society that continues to make that difference matter. Both sides of the dilemma appear and reappear in the history of education for students who are not native English speakers.

2. Special Education. A contrasting history appears for education for the handicapped, but here, too, the dilemma of difference appears and reappears. As frequently told, this history emphasizes the exclusion of exceptional chil-

32. Silberman, Crisis in the Classroom 58 (1970) (quoting Leonard Covello).

33. Ridge, The New Bilingualism: An American Dilemma, in The New Bilingualism: An American Dilemma 259, 260 (M. Ridge ed. 1981). A Hispanic school administrator explained, "You tell the child: 'Your language is second-rate and you shouldn't speak it. Your culture is second-rate and you need to be something else. . . . What you are in fact saying to the kids is 'You are second-rate.'" Lanier, Teaching with Subtitles, Chi. MAG. at 163, 191 (June 1984) (quoting Jose Gonzales, Associate Superintendant of Chicago Board of Education).

34. R. Rodriguez, Hunger of Memory: The Education of Richard Rodriquez 19 (1982) (emphasis in original). Even though they differ in their views on bilingual education, both Covello and Rodriguez understand schooling as a process of transferring loyalties and transforming identities. 
dren from mainstream classrooms or from schooling altogether. ${ }^{35}$ This history is complicated by the broad, ambiguous, and shifting conception of handicap; exceptional children can include children with developmental disabilities, emotional disturbances, learning or perceptual disabilities, sensory deficits, mobility impairments, and each of these definitional categories has shifted over time. Nonetheless, a general historical picture of the educational opportunities for exceptional children depicts the gradual but steady progress toward recognizing what these children share with other children, rather than emphasizing their differences. It is thus a story of expanding humanitarianism and increasing inclusion of handicapped children in the worlds of education, training, and social life.

The story begins before schooling was compulsory, when local authorities had discretion to exclude children from public education on the grounds of ineducability, and communities tended to consider handicaps as barriers to adult responsibilities. As a result, until the Civil War, children with special needs were usually hidden in poorhouses. Humanitarian reforms, led by physicians in both Europe and the United States, produced special institutions for the deaf and for the blind during the early part of the nineteenth century. ${ }^{36}$ Local policies segregated the disabled in institutions removed from the community. ${ }^{37}$

After the Civil War, as many communities adopted compulsory education laws and then began to enforce them, exceptional children began to present themselves in increasing numbers to public schools. Educators responded with separate day schools-and separate classes within existing schools-for the deaf, the mentally retarded, the crippled, and other groups of children identified with the handicap labels of that time. Previously consigned to institutions or locked away at home, during this later period children with special needs at least had a place, and a chance for some education and attention. ${ }^{38}$ Some recent versions of this history emphasize the interaction between proliferating separate classes for special children and the influx of new immigrants to the community and the community schools. ${ }^{39}$ This isolation of minority groups in special education classes drew attention to the similarities between special education and education segregated by race or ethnicity. ${ }^{40}$ At the

35. See, e.g., Stark, Tragic Choices in Special Education: The Effect of Scarce Resources on the Implementation of Pub. L. No. 94-142, 14 Conn. L. Rev. 477, 479-80 (1982).

36. Reformers established in Hartford, Connecticut, a residential institution offering training and a protective environment for the deaf in 1817 . Schools for the blind were established around the same era; by the time of the Civil War, such institutions were common. S. Kirk \& J. Gallagher, Educating Exceptional Children 4-5 (3d ed. 1979).

37. F. Hewett \& S. Forness, Education of Exceptional Learners 32-41 (1974).

38. E.g., S. Sarason \& J. Doris, Educational Handicap, Public Policy, and Social History 232 (1978); Cruickshank, The Development of Education for Exceptional Children, in EducaTION OF EXCEPtional Children and Youth 11-12 (W. Cruickshank \& P. Xurland 3d ed. 1975); Tyack, Ways of Seeing: An Essay in the History of Compulsory Schooling, 46 Harv. Educ. REv. 355 (1976).

39. S. Sarason \& J. Doris, supra note 38 , at 245.

40. See Hobson v. Hansen, 269 F. Supp. 401 (D.D.C. 1967), affd sub nom. Smuck v. Hobson, 408 F.2d 175 (D.C. Cir. 1969) (en banc); Larry P. v. Riles, 343 F. Supp. 1306, 1309 (N.D. Cal. 1972), affd, 502 F.2d 963 (9th Cir. 1974). 
same time, social scientists uncovered the psychological detriment to a child from being labeled as different and inferior. ${ }^{41}$ The harmful effects of separate treatment became the focus of the culminating chapter in this story of the progressive inclusion of handicapped children.

During the 1970's, law reformers pushed for both expanding the services for special education and educating the exceptional child with his or her "normal peers to whatever extent is compatible with potential for the fullest development." 42 Two landmark federal district court cases produced stipulated relief to this effect, ${ }^{43}$ and state and federal legislation between 1970 and 1978 incorporated these mainstreaming goals. ${ }^{44}$ What happened during the intervening decades to yield this trend toward integrating or "mainstreaming" exceptional children? Building on the civil rights movement and Brown v. Board of Education, ${ }^{45}$ educational reformers sensitized the legal community to the stigma of separate treatment, the risks of misclassification and labeling in creating stigma and low self-esteem, and the abusive use of separate classes to perpetuate discrimination against racial and ethnic minorities. ${ }^{46}$ Legal reformers in turn adopted a due process tack to promote accountability by public decisionmakers and individualized consideration of students, just as the due process doctrine had previously been used to help recipients of public benefits. In the special education context, litigators and legislators used the due process doctrines to structure procedural and substantive protections for handicapped children who were excluded from public schooling. ${ }^{47}$ These legal frameworks provided a rhetoric for treating excep-

41. Stigma from segregation, of course, emerged as a psychological detriment in the context of racial desegregation. See Brown v. Board of Educ., 347 U.S. 483, 494 n.11 (1954). But cf. Levin \& Moise, School Desegregation Litigation in the Seventies and the Use of Social Science Evidence: An Annotated Guide, Law \& Contemp. Probs., Winter 1975, at 50, 53-56 (since Brown, courts have questioned use of social science research in regard to the question of whether a constitutional violation ocurred, but have used them to fashion remedies); Yudof, School Desegregation: Legal Realism, Reasoned Elaboration, and Social Science Research in the Supreme Court, Law \& Contemp. Probs., Autumn 1978, at 57, 69-71 (noting limitations of social science methodology applied in Brown v. Board of Educ.). The relationship between handicap labeling and stigma became a major issue in social services during the 1970's. See J. Mercer, Labeling the Mentally Retarded: Clinical and Social System Perspectives on Mental Retardation 31, 82 (1973) (service providers should be aware of links between social systems, status, and handicap labels); J. Shrybman, Due Process in Special Education 6 (1982) (due process concerns about reputational interest threatened by labeling).

42. S. Kirk \& J. Gallagher, Educating Exceptional Children 7 (1979).

43. Mills v. Board of Educ., 348 F. Supp. 866 (D.D.C. 1972) (court-ordered remedy, including order for comprehensive plan by defendants); Pennsylvania Ass'n for Retarded Children (PARC) v. Pennsylvania, 343 F. Supp. 279 (E.D. Pa. 1972) (consent agreement).

44. See Zettel \& Abeson, The Right to a Free Appropriate Public Education, in THE CourTs AND EDUCATION 188, 198-99 (C. Hooker ed. 1978) (77th Yearbook of the National Society for the Study of Education) (describing legislative developments).

45. 347 U.S. 483 (1954).

46. Hobson v. Hansen, 269 F. Supp. 401 (D.D.C. 1967), affd sub nom. Smuck v. Hobson, 408 F.2d 175 (D.C. Cir. 1969) (en banc) (illicit use of tracking to perpetuate racial segregation); see, e.g., Kirp, Buss, \& Kuriloff, Legal Reform of Special Education: Empirical Studies and Procedural Proposals, 62 Calif. L. Rev. 40, 46 (1974) (misclassification).

47. See Pennsylvania Ass'n for Retarded Children (PARC) v. Pennsylvania, 334 F. Supp. 1257 (E.D. Pa. 1971) (per curiam) (injunction and consent agreement), 343 F. Supp. 279 (E.D. Pa. 1972) (injunction and amended consent agreement); Mills v. Board of Educ. 348 F. Supp. 866 (D.D.C. 1972). 
tional children as, first and foremost, persons entitled to legal and educational rights. The rhetoric could also advance their inclusion, at least conceptually, in the larger community.

The history of special education thus depicts increasing faith in the educability of special needs children and growing commitment to grant them entry to the social life of other children. Yet the dilemma of difference recurs. On the one hand, ever more sophisticated methods to recognize varieties of handicapping conditions identify increasing numbers of children as different and therefore entitled to some specialized instruction. On the other hand, increasing commitment to treat special needs children like other children cautions against this very result, or argues for creating facsimiles of the mainstream classroom in special schools or in classes for those with special needs. Making difference matter recreates difference and its associated hierarchy of status; making difference not matter, though, may cause the same result. Even given their contrasting histories, both bilingual and special education highlight this dilemma.

\section{Legal and Programmatic Structures}

As a result of federal and state litigation and legislation during the past several decades, a welter of legal authorities have emerged to construct and define the programs known as bilingual and special education. In addition, competing program types have emerged in both areas. These legal and programmatic structures share complexity, but diverge in shape and content. Nonetheless, the underlying difference dilemma can help explain points of confusion and contention in these programmatic structures.

1. Bilingual Education: Legal Framework and the Difference Dilemma. When the Supreme Court decided Lau v. Nichols ${ }^{48}$ in 1974, it accepted the claim of nonEnglish speaking Chinese students that instruction solely in English denied them "a meaningful opportunity to participate in the educational program," and it construed Title VI of the Civil Rights Act of 1964 to supply a legal basis for demanding special instruction for language minority students in schools receiving federal financial assistance. The Court thereby linked affirmative obligations to provide language instruction to the statutory requirement that "[n]o person in the United States shall, on the ground of race, color, or national origin, be excluded from participation in, be denied benefits of, or be subjected to discrimination under any program or activity receiving Federal financial assistance." 49 The Court refrained, however, from detailing the form such language instruction must or should take. Indeed, the Court noted that no particular remedy was requested by the plaintiffs: "[ $t$ ]eaching English to the students of Chinese ancestry who do not speak the language is one choice. Giving instruction to this group in Chinese is another. There may be

48. 414 U.S. 563 (1974).

49. Title VI of the Civil Rights Act of 1964, 42 U.S.C. $\S 2000 \mathrm{~d}$ (1982). 
others." 50

It could be argued that anything but immersion in the mainstream classroom violates the plain language of Title VI; what made Lau an impressive decision was the Court's recognition of an experiential context in which such mainstreaming, with no attention to language and cultural differences, constituted, for the Chinese-speaking plaintiffs, exclusion, denied benefits and discrimination. In this respect, the Lau decision resembles the Court's opinion in Loving $v$. Virginia, ${ }^{51}$ where the social meaning of majority-minority differences was a factor in the Court's rejection of a miscegenation statute. The Court concluded that although the miscegenation law equally forbade blacks and whites from marrying each other, in the context of a national history of discrimination against nonwhites, this law reinforced the stigma against the minority race and thus unconstitutionally discriminated. In Loving, a straightforward legal rejection of the miscegenation statute did not recreate the difference dilemma in the construction of a legal remedy, ${ }^{52}$ yet the $L a u$ decision could not avoid this dilemma in developing legal alternatives. State decisions remain to be made about how to treat minority language children in the public schools. The generality of the language adopted in the Civil Rights Act-undoubtedly without the Lau problem in mind-is commodious enough to support contrasting remedial alternatives, any of which may well continue to stigmatize the children who are different. The dilemma of difference, then, remains for decisions based on the reasoning of Lau.

The second legal framework for bilingual education, the Bilingual Education Act, as amended by the Equal Educational Opportunity Act, ${ }^{53}$ also presents the difference dilemma. The Bilingual Education Act acknowledges the need for both English language and native language instruction, but obscures the critical choice between integration and segregation and between English usage and native language usage by directing that the mix of languages "shall, to the extent necessary, be in all courses or subjects of study which will allow a child to progress effectively through the educational

50. 414 U.S. at 564-65.

51. 388 U.S. 1 (1967).

52. The Court in Loving did not need to craft a new law; it just struck down the law under challenge. Yet even though the Court could escape the difference dilemma, eliminating the law against miscegenation hardly eliminates the difference dilemma for an interracial couple contemplating marriage in some contemporary American communities. Their marriage, premised on their belief that their racial differences should not matter, may expose both them and their children to the risks of stigma. Cf. Palmore v. Sidoti, 426 So. 2d 34 (Fla. Dist. Ct. App. 1982) (affirming without opinion trial court's holding that change of custody for white daughter was warranted where white mother married black man since children of interracial marriage would be stigmatized), rev'd, $104 \mathrm{~S}$. Ct. 1879 (1984) (acknowledging risks to the child from custody with interracial couple but rejecting this as basis for state imposed change in custody). However, a decision on their part not to marry surely just as much reconfirms the stigmatizing, discriminatory dimensions of difference as it has come to have social meaning. See also M.P. v. S.P., 169 N.J. Super. 425, 438, 404 A.2d 1256, 1263 (1979) (judge explains that removing children from custody of lesbian mother to protect them from community disapproval would teach them to leave their problems and to believe that loved ones should be abandoned if others dislike them).

53. 20 U.S.C. $\$ \S 3221-3261$ (1982). 
system."54 The critical choices, then, are to be resolved with reference to undefined terms such as "to the extent necessary," and "to progress effectively through the educational system"-where the meanings of "necessary" and "effective progress" may be themselves changed by the introduction of bilingual education. Similarly, the Equal Educational Opportunity Act leaves critical terms undefined and thereby preserves the difference dilemma; depending on terms like "appropriate," and "equal participation," 55 the Act preserves the dilemma about whether to avoid discrimination by constructing special and separate programs or by pushing the different child into participation in the mainstream class.

2. Bilingual Programs and the Difference Dilemma. In the face of this remedial ambiguity, federal courts and agencies developed a range of possible programs. As implemented by local school boards and school staff, varied programs abound. ${ }^{56}$ Grouping the programs into two major kinds of programs can serve to highlight this variety and also to underscore the continuing remedial ambiguity in legal developments since Lau.

a. Types of Bilingual Programs. The first type of program, called "English as a Second Language Instruction" (ESL), has been defined by the federal government as "[a] structured language acquisition program designed to teach English to students whose native language is not English."57 Typically, ESL provides intensive instruction in English, with the goal of enabling the student to speak and understand English as soon as possible, and employs the "pull out" method: the language minority student spends most of the school day in the regular class without language assistance, and the student is pulled out of the mainstream class during part of the day for ESL instruction. ESL does not, then, use native language instruction to conduct substantive classes in, say, math or social studies, while the student is gaining mastery of English;

54. 20 U.S.C. $\$ 3223(\mathrm{a})(4)(\mathrm{A})(\mathrm{i})(1982)$.

55. "No state shall deny equal educational opportunity to an individual on account of his or her race, color, sex, or national origin by. . .(f) the failure by an educational agency to take appropriate action to overcome language barriers that impede equal participation by its students in its instructional programs." 20 U.S.C. $\$ 1703$ (1982).

56. See Baker \& de Kanter, Federal Policy and the Effectiveness of Bilingual Education, in BiLINGUAL Education: A Reappraisal of Federal Policy 33, 34-35 (K. Baker \& A. de Kanter eds. 1983) (describing English as a second language (ESL), structured immersion, and transitional bilingual education); Carpenter-Huffman \& Samulon, Case Studies of Delivery and Cost of Bilingual Education, in Bilingual Education: A Reappraisal of Federal Policy, supra, at 141, 145-50 (describing variety of instructional methods and choices among self-contained classrooms and pull-out programs); see also S. Goldstein \& E. Gee, Law and Public Education: Cases and Materials 801 (1980) (describing 1) segregation of non-English speaking students in classrooms where instructors use English and their own language; 2) segregated students taught in their own language and instructed in English as a second language; 3 ) integrated classroom where both English and other language are used; and 4) English as a second language, placing minority students in mainstream classroom with supplementary English instruction). Thus, programs may differ in both the mix of services they combine and the setting in which the services are offered.

57. Office for Civil Rights, U.S. Dep't of Health, Education and Welfare, Task Force Findings Specifying Remedies for Eliminating Past Educational Practices Ruled Unlawful. Under laU $\boldsymbol{V}$. Nichols (1975), reprinted in Bilingual Education: A Reappraisal of Federal Policy 213, 221 (1983) [hereinafter cited as LAU Guidelines]. 
nor does ESL expose the English-speaking students to the language or culture of the non-English-speaking students. ${ }^{58}$

A variant on this model, called "transitional bilingual education," also aims for transition from special treatment to total integration in the regular classroom. Under this approach, subject matter instruction may temporarily be conducted in the children's home language until their proficiency in English improves enough to enable participation in the regular classroom. ${ }^{59}$ Because both the transitional variation and ESL seek to integrate the minority language student in mainstream classes, any segregation under these programs is intended to be temporary. Nonetheless, segregated instruction often stretches longer than planned since the child may have fallen behind the mainstream class in other subjects or may perform less successfully because of the prior language barrier.

The second major type of program, commonly called bilingual-bicultural education, combines native language instruction in substantive courses, ESL training, and instruction in the culture and history of both America and the nation or group associated with the student's native language. Programs are additionally distinguishable by whether their cultural emphasis addresses "surface" culture, such as crafts and music, or "deep" culture, such as attitudes about family, health, and sex roles. ${ }^{60}$ In 1975, the U.S. Commission on Civil Rights identified six objectives in this kind of program: (1) fostering the student's healthy self-image; (2) developing cognitive powers; (3) creating an atmosphere not totally alien to the child's familiar environment; (4) developing reading skills; (5) teaching language skills systematically; and (6) improving English skills. ${ }^{61}$ Although the Supreme Court did not specify a preference for bilingual-bicultural programs, the Department of Health, Education and Welfare did so after Lau in advisory form. ${ }^{62}$ Subsequent legal developments; however, complicated both federal and state postures on this issue.

b. Post-Lau Legal Developments. Shortly after Lau, the Supreme Court decided Regents of the University of Califormia $v$. Bakke, ${ }^{63}$ which reopened the issue of what affirmative obligations public educational institutions might have to minorities; Bakke required demonstration of discriminatory intent before affirmative remedies could be ordered by school authorities. Next, Congress itself increased federal support for bilingual programs; building on

58. See S. Goldstein \& E. GeE, supra note 56, at 801.

59. Birman \& Ginsberg, Addressing the Needs of Language-Minority Children, in Bilingual EducAtion: A Reappraisal of Federal Policy xi-xii (1983). See also Lau Guidelines, supra note 57, at 221. The task force report particularly opposed ESL for elementary school students unless modified through the transitional method. Id. at 215.

60. Gonzales, Reinforcing Culture in Three Bilingual Education Programs, in Early Childhood Bilingual. Education: a Hispanic Perspective 93, 96-99 (T. Escobedo ed. 1983).

61. U.S. Commission on Civil Rights, Bilingual-Bicultural Education: A Better Chance to Learn 1, 29-30 (Clearinghouse Publication 51, 1975).

62. LAU Guidelines, supra note 57, at 215-18.

63. 438 U.S. 265 (1978). 
the 1968 amendment to the Elementary and Secondary Education Act, Congress adopted amendments in 1974 and in 1978 which expanded the target population for federally-aided services. ${ }^{64}$ Congress did not oblige local school authorities to adopt bilingual-bicultural programs in implementing equal opportunity requirements; instead, the statutes preserved local school discretion on this issue. ${ }^{65}$ The statutory definition of "program of bilingual education" employed the flexible language of "to the extent necessary" regarding both the use of the child's native language and the integration of bicultural materials with other subjects. ${ }^{66}$ Although some have argued that the federal commitment continued to favor bilingual-bicultural programs, ${ }^{67}$ the legislative and administrative record itself is unclear. Federal judicial interpretation of these statutes has also produced ambiguous results. ${ }^{68}$ The legal ambiguity, which may have emerged from political conflict, promotes continued political battles among interest groups over which of the permitted types of programs for minority language students should be used. ${ }^{69}$

64. See Bilingual Education Act of 1968, Pub. L. No. 90-247, tit. VII, $\S \S 701-708,81$ Stat. 783; Act of Nov. 1, 1978, Pub. L. No. 95-561, tit. 7, $\$ 702,92$ Stat. 2143 (amendment expanding services to students with limited proficiency in reading, writing, and speaking English); Act of Aug. 21, 1974, Pub. L. No. 93-380, tit. 7, § 702, 81 Stat. 484 (expanding services beyond low income children) (current version at 20 U.S. $\S \S 3221-3261$ (1982)); see also Morales v. Shannon, 516 F.2d 411, 415 (5th Cir. 1975), cert. denied, 423 U.S. 1034 (1975) (unlawful educational practice to fail to take appropriate action to overcome language barriers); Equal Educational Opportunity Act, 20 U.S.C. \$ 1703(f) (1982) (prohibiting "failure by an educational agency to take appropriate action to overcome language barriers that impede equal participation").

65. See 20 U.S.C. \& 3222 (1982) (federal grants program). State legislation also generally does not specify which form of bilingual program schools must use. See e.g., Tex. Educ. Code AnN., \$ 21.451; (Vernon Supp. 1973) (requiring bilingual instruction). But see Mass. ANN. Laws ch. 71A, $\S \S 1-9$ (Law. Co-op. 1978) (requiring transitional program but including instruction in history and culture of native language speakers).

66. Thus, the statute defines a "program of bilingual education" in elementary and secondary schools as a program where "there is instruction given in, and study of, English and, to the extent necessary to allow the child to achieve competence in the English language, the native language of the children of limited English proficiency, and such instruction is given with appreciation for the cultural heritage of such children, and of other children in American society, and, with respect to elementary and secondary school instruction, such instruction shall, to the extent necessary, be in all courses or subjects of study which will allow a child to progress effectively through the educational system . . . "20 U.S.C. $\$ 3223$ (a)(4)(A)(i) (1982).

67. See N.Y. Times, May 14, 1983, at 22, col. 1 (editorial page) (criticizing federal "blessing" for native language maintenance programs). The regulations proposed but never implemented under the Carter administration would have required bilingual instruction for eligible students instead of ESL, 45 Fed. Reg. 52,052 (1980) (proposed regulation), but as the Secretary of Education later described, these regulations were intended "to require school districts to teach non-English proficient youngsters English as quickly as possible, and, while the children were learning English, to give them instruction in required courses in a language they could understand." Hufstedler, Is America Over-Lawyered?, 31 Clev. ST. L. Rev. 371, 380 (1982); see also Haft, Assuring Equal Educational Opportunity for Language-Minonity Students: Bilingual Education and the Equal Educational Opportunity Act of 1974, 18 Colum. J.L. \& Soc. Probs. 209, 258-63 (1983) (arguing that Congressional and administrative authority favored bilingual programs).

68. Compare Cintron v. Brentwood Union Free School Dist., 455 F. Supp. 57, 62-64 (E.D.N.Y. 1978) (requiring bilingual and bicultural instructional methods) with Rios v. Read, 480 F. Supp. 14, 22 (E.D.N.Y. 1978) (requiring temporary bilingual instruction) and Guadalupe Org., Inc. v. Tempe Elementary School Dist., 587 F.2d 1022, 1030 (9th Cir. 1978) (approving nonbilingual-bicultural program to meet the needs of language-minority students).

69. See Hufstedler, supra note 67, at 380-81 (discussing public debate over federal regulations); Daley, Panel Asks Stress on English Studies, N.Y. Times, May 6, 1983, at 1, col. 1 (debate among Hispanic 
The contrast between ESL instruction and bilingual-bicultural instruction illustrates the most obvious contrast between the different solutions to the dilemma; the continuing debate between the two models demonstrates how the dilemma structures common understandings. ESL proposes short-term segregation during part of the school day, and long-term integration, with an abandonment of minority identity, in the school context. Its critics argue that the program reconfirms the association of difference with inferiority by refusing to recognize the positive experiences of minority difference and by failing to instruct either minority or majority children in the minority language and culture. Bilingual-bicultural programs attempt to meet this criticism, but in turn encounter the other side of the dilemma. By reinforcing minority difference and prolonging separation, such programs risk reconfirming the identification of difference with alien and inferior status and also risk failing to prepare their students for a society that makes mastery of English language and American culture a precondition for success.

3. Special Education Law and the Difference Dilemma. The legal framework for special education combines a general ban on discrimination to protect the handicapped in any program receiving federal funds and a categorical assistance grant program which conditions the grants on statewide compliance with substantive and procedural requirements to educate exceptional children. The general antidiscrimination ban, section 504 of the Rehabilitation Act of $1973,{ }^{70}$ follows the model of the Civil Rights Act of $1964,{ }^{71}$ which supplied the basis for the Lau $v$. Nichols decision and which forbids exclusion from or denial of benefits due to an individual's race, color or national origin. Section 504 in part borrows the same structure-forbidding exclusion of or denial of benefits to a member of the protected group, here handicapped persons, by any program receiving federal support. Section 504 also adds the requirement that the protected minority group member, here a handicapped person, be "otherwise qualified" for the program or benefits before the provisions of the law may apply. ${ }^{72}$ Thus, section 504 describes with considerable ambiguity the group it actually protects; the statute does not clearly indicate whether it covers persons qualified except for their handicap or persons qualified even given their handicap. Southeastern Community College v. Davis ${ }^{73}$ presented this definitional ambiguity, and the Supreme Court found that section 504 did not require the school to undertake affirmative steps to accommodate the needs

and education communites over programs for English proficiency.); Lopez, Bilingual Schooling Comes Under Review, The Sunday Record, Jan. 31, 1982, at 1, col. 6 (Bergen/Passaic/Hudson Counties, New Jersey) (state legislation debated to alter bilingual programs developed under federal law).

70. 29 U.S.C. $\$ 794$ (1982): "No otherwise qualified handicapped individual in the United Sates . . . shall, solely by reason of his handicap, be excluded from participation in, be denied the benefits of, or be subjected to discrimination under any program or activity receiving Federal financial assistance..."

71. Pub. L. No. 88-352, 78 Stat. 241 (codified as amended at 42 U.S.C. $\$ \S 2000$ a to $2000 \mathrm{~h} \cdot 6$ (1982)).

72. See supra note 70.

73. 442 U.S. $397,407,413$ (1979). 
of a deaf student in a college nursing program. The case did not, however, resolve the issue of the coverage of the section in any more general fashion. The Court concluded that "[a]n otherwise qualified person is one who is able to meet all of a program's requirements in spite of his handicap," 74 but also reasoned that a refusal to modify an existing program to accommodate a handicapped person could amount to illegal discrimination. ${ }^{75}$ The Court's decision left case-by-case analysis as the likely mode for interpreting the law. ${ }^{76}$

The second federal statute framing special education policy is commonly known as the Education for All Handicapped Children Act (EAHCA). ${ }^{77}$ Its complicated terms produce programmatic choices for local authorities which deserve some elaboration. The difference dilemma highlights both the statutory commitments and the programmatic choices.

As a state or local activity, public education receives major funding from state and local sources. Through the EAHCA, however, the federal government provides financial incentives for state provision of special services for handicapped children. ${ }^{78}$ To obtain grants under the Act, an applicant state must submit a plan on a yearly basis which details how the state intends to meet the Act's objectives; the federal objectives, then, are adopted by the state in exchange for accepting federal assistance. The Act's objectives include (1) identifying all handicapped children needing special education and related services; ${ }^{79}$ (2) protecting rights of children and their parents to nondiscrimination in the evaluation and placement process and confidentiality in the handling of personally identifiable data;80 and (3) mainstreaming, or integrating

74. Id. at 406 .

75. Id. at 411-12.

76. See Note, Employment Discrimination Against the Handicapped and Section 504 of the Rehabilitation Act: An Essay on Legal Evasiveness, 97 HARv. L. REv. 997, 1009 (1984). See generally Wegner, The Antidiscrimination Model Reconsidered: Ensuring Equal Opportunity Without Respect to Handicap Under Section 504 of the Rehabilitation Act of 1973, 69 CORNELL L. REv. 401, 452-58 (1984) (discussing Southeastern Community College v. Davis, 442 U.S. 397 (1979)).

77. Pub. L. No. 94-142, 89 Stat. 773 (1975) (codified as amended at 20 U.S.C. $\$ \S 1400-1461$ (1982)). See generally Stark, Tragic Choices in Special Education: The Effect of Scarce Resources on the Implementation of Pub. L. No. 94-142, 14 ConN. L. Rev. 447, 479-84 (1982) (describes how EAHCA works); Note, Enforcing the Right to an "Appropriate" Education: The Education for All Handicapped Children Act of 1975, 92 HARv. L. REv. 1103, 1104-08 (1979) (discusses history of EAHCA and statutory framework).

78. 20 U.S.C. $\S \S 1411-1420$ (1982) (grant programs). Also, the Act defines "handicap" broadly; and its interpretive regulations focus on whether a child has an impairment and because of that impairment needs special education and related services. 34 C.F.R. $\$ 300.5$ (a) (1984). Aside from such defined impairments as deafness and mental retardation, the regulations also identify "other health impaired" conditions that "adversely affects a child's educational performance." Id. $\S 300.5(\mathrm{a})(7)$; see also id. $\S 300.5$ (a)(8)(i) ("seriously emotionally disturbed" conditions defined as one or more characteristics "which adversely affect educational performance").

79. "Related services" are noneducational services that may be essential if a handicapped student is to benefit from education; such services can include transportation, speech pathology, psychological services, physical therapy, and diagnostic medical services. 20 U.S.C. \& 1401(17) (1982); 34 C.F.R. $\& 300.13$ (1984). Litigation over the definition of "related services" under the Act has been extensive. See, e.g., Irving Indep. School Dist. v. Tatro, 104 S. Ct. 2379 (1984) (heart catheterization is covered); In re San Mateo County Sup't of Schools, 1980-81 Educ. Handicapped L. ReP. (CRR) 502:199 (Cal. SEA 1980) (sign language instruction for child's parents covered).

80. 20 U.S.C. $\S 1412(5)(C)(1982)$ (testing and evaluation procedures not to be racially or cul- 
handicapped children with nonhandicapped. ${ }^{81}$ While the federal government leaves to each participating state the task of detailing the actual programs it will use to achieve these goals, the EAHCA specifies a set of substantive and procedural rights that each participating state must endorse. Substantively, each participating state must guarantee every handicapped child a "free appropriate public education" 82 and an education in the "least restrictive environment" possible-which means mainstreaming the child in a classroom with nonhandicapped children if possible, or if not, then the closest approximation that can serve the child's needs. ${ }^{83}$ Exactly what these substantive requirements mean for individual children has emerged as a legal battleground. ${ }^{84}$

Such disputes become comprehensible as expressions of the difference dilemma. Whether and how much to mainstream an exceptional child clearly presents the issue of whether to respond to difference by separation or by integration. The problem is whether in order to overcome stigma, social isolation, and inter-group misunderstanding, a child with a severe hearing impairment should be enrolled in a mainstream classroom ${ }^{85}$ or instead in a special class or school for deaf children. As with analogous issues in bilingual education, the dilemma truly presents two sides: a deaf student may experience the pain of attributed inferiority and isolation amid a class of hearing

turally discriminatory); 20 U.S.C. $\$ 1417$ (c) (1982) (protection of rights and privacy of parents and students).

81. 20 U.S.C. $\$ 1412(5)$ (B) (1982). See J. Shrybman, supra note 41, at 13-14 (discussing statutory purposes).

82. 20 U.S.C. \& 1401(18) (1982): "The term "free appropriate public education" means special education and related services which (A) have been provided at public expense, under public supervision and direction, and without charge; (B) meet the standards of the state educational agency; (C) include an appropriate preschool, elementary, and secondary school education in the state involved; and (D) are provided in conformity with the individualized education program required under section $1414(\mathrm{a})(5)$ of this title."

83. To qualify for federal financial assistance, a state should demonstrate that it established "procedures to assure that, to the maximum extent appropriate, handicapped children, including children in public or private institutions or other care facilities, are educated with children who are not handicapped, and that special classes, separate schooling, or other removal of handicapped children from the regular educational environment occurs only when the nature or severity of the handicap is such that education in regular classes with the use of supplementary aids and services cannot be achieved satisfactorily." 20 U.S.C. $\$ 1412(5)$ (B) (1982). As with bilingual programming, programs may differ in both the mix of services provided, and the setting where the services are offered; the requirement of "appropriate" education may refer to both the setting and the mix of services, while the requirement of the "least restrictive" placement refers to the setting-but may influence the mix of services and their delivery.

84. See Board of Educ. v. Rowley, 458 U.S. 176 (1982); Armstrong v. Kline, 476 F. Supp. 583 (E.D. Pa. 1979), remanded on other grounds, Battle v. Pennsylvania, 629 F.2d 269 (3d Cir. 1980), cert. denied, 452 U.S. 968 (1981) (self-sufficiency education). See generally Comment, Self-Sufficiency Under the Education of All Handicapped Children Act: A Suggested Approach, 1981 Duke L.J. 516, 519-27 (1981) (discussing varied interpretations of statute's substantive requirements); Neal \& Kirp, The Allure of Legalization Reconsidered: The Case of Special Education, Law \& ConTEMP. Probs., Winter 1985, at 63, 71 . 72 (substance of rights for handicapped children unspecified by law; elaboration depends on individual education plan); Note, Legal Remedies for the Misclassification or Wrongful Placement of Educationally Handicapped Children, 14 Colum. J.L. \& SoC. ProBs. 389 (1979) (discussing litigation challenging over-classification and under-classification affecting placement and services)

85. This option could involve some special instruction during part of the school day. See infra notes 135-43 and accompanying text (discussing Board of Educ. v. Rowley, 458 U.S. 176 (1982)). 
children, but he or she may have a similar experience of stigma and alienation from segregation in the separate class for deaf children. Although the statutory commitment to the "least restrictive" placement might support the mainstream classroom placement, the statutory commitment to the "appropriate" educational placement could be used to support an alternative, and the language of the statute itself does not resolve this choice. ${ }^{86}$

Cost concerns, of course, are likely to influence the placement choices. Although the requirement of the least restrictive alternative was endorsed by Congress to overcome the detriment ${ }^{87}$ and isolation experienced by children in such placements, least restrictive placements may be pushed in practice by the school departments confronting budgetary constraints. The administration thus may favor "mainstreaming" or providing some other placement that is cheaper than totally separate instruction. In that case, the placements may fail to provide the benefits of an education appropriate to the particular child's needs, as required by the Act. An extreme case arises with residential schooling, perhaps the most restrictive alternative and the most expensive placement option, and yet conceivably the appropriate placement for some severely disabled children. Regulations promulgated to implement the EAHCA mandate that when residential placement is "necessary to provide special education and related services to a handicapped child, the program, including non-medical care and room and board, must be provided at no cost to the parents. . . " 88 Parents who prefer a residential placement for their children even when the placement process yields a nonresidential placement must assume the costs of the placement themselves. With such considerable sums of money involved, it is not surprising that residential programming issues are the most frequently litigated topic in special education. ${ }^{89}$ Parents favoring residential placements have prevailed or obtained opportunities for reconsideration of adverse school decisions in cases where the school system committed procedural errors in the placement process ${ }^{90}$ and where the resi-

86. If the statute had included only one of the terms-appropriate or least restrictive-the ambiguity would remain because both terms can be used to support contrasting placements. The statute's inclusion of both terms exposes on the surface of the law the tension between mainstreaming goals and tailor-made education responding to the "different" student.

87. One possible detriment, asserted by some critics, is that programs for disabled people may create the disability alleged. See S. Sarason \& J. Doris, supra note 38, at 42 (describing "iatrogenic retardation-a form of intellectual retardation that is induced by the very system designed to foster intellectual development"). See generally An Alternate Textbook in Special Education (1977) (criticizing creation of inequality based on assumed disabilities). One special education teacher described the instance of a misdiagnosed child who manifested the symptoms associated with the diagnosis-and whose parents reinforced and expected those symptoms in the child. "She had been in a classroom with a lot of kids who had cerebral palsy. When we started changing that, the parents took her out of the program. Because 'You're changing our daughter!' They didn't like that at all." K. Howell, Inside Special Education 27 (1984).

88. 34 C.F.R. § 300.302 (1984).

89. See Mooney \& Aronson, Solomon Revisited: Separating Educational and Other Than Educational Needs in Special Education Residential Placements, 14 ConN. L. Rev. 531 (1982).

90. See, e.g., Lang v. Braintree School Comm., 545 F. Supp. 1221, 1228 (D. Mass. 1982) (failure to include parents in IEP planning process); Matthews v. Ambach, 552 F. Supp. 1273, 1278.79 (W.D.N.Y. 1982) (deaf child permitted to sue for monetary damages after delay in school placement decision). 
dential placement preserved the status quo or educational progress of the child. ${ }^{91}$ School systems have prevailed by demonstrating that day-school placements are appropriate even if, on a comparative basis, they are less appropriate than residential placements. ${ }^{92}$ The statutory framework itself structures this set of arguments, while the cost concerns propel the schools, and the desire to maximize services motivates the parents.

Where less restrictive placements, like special classes, are at issue for students with behavioral or learning problems, the teacher's interests may counter the school administration's desire to provide a cheaper placement than the "appropriate" one authorized by statute. In this context, teachers may push for an "appropriate" placement outside the mainstream classroom. 93 This very rhetoric of "appropriate" placements may, in use, conflict with the statute's simultaneous commitment to the least restrictive placement. After all, the commitment to the least restrictive alternative was devised in part to combat this very reluctance of the classroom teacher to deal with the unusual or more difficult child. One special education teacher explained that some teachers

think these kids really don't belong in the classroom or in the school, for that matter. They just basically refuse to teach them. . . . Teacher contracts don't stipulate certain kinds of kids - they just stipulate that you will teach a certain subject matter or grade level. It is not right that some teachers decide not to do their job because a kid isn't behaving the way the teacher prefers. I think we've gotten to the point now where we select out the LD [learning disabled] kids and send them off to LD classrooms, the $\mathrm{EH}$ [emotionally handicapped] kids go to $\mathrm{EH}$ classrooms, the hearinghandicapped go to hearing-handicapped classrooms, visually-impaired go to visuallyimpaired classrooms, and the physically handicapped go off somewhere else, and the gifted go off to Europe and study paintings, or whatever the hell they do. By the time you pull them all out, you've got this little core group of average WASPs, and that's kind of frightening to me . . . [so] I do a lot of reinforcement of the regular classroom teachers who are willing to work, or at least attempt to work with the kids that I phase back in the regular classes. ${ }^{94}$

The teachers' expectations, then, can lead them to define as different many student subgroups by reference to the statutory commitment to serving individual student's needs. Again, the ambiguity preserved by the statutory commitments to both the "least restrictive" and the "appropriate" education permit the incentives of teachers, the desires of parents, and the pressures of budgets to give content to the law. The statutory ambiguity itself preserves

91. See, e.g., Lang v. Braintree School Comm., 545 F. Supp. 1221, 1228 (D. Mass. 1982); Appel v. Ambach, 1982-83 Educ. HandiCapped L. ReP. 554:236 (S.D.N.Y. 1982) (emotionally-disturbed child; case remanded for completion of IEP).

92. See, e.g., Hessler v. Board of Educ., 700 F.2d 134 (4th Cir. 1983) (also by demonstrating that parents failed to pursue administrative remedies); Cain v. Yukon Pub. Schools, 556 F. Supp. 605 (W.D. Ok. 1983).

93. See Massachusetts Dep't of Educ., Final Report: Implementing Massachusetts' Special Education Law: A Statewide Assessment 56 (1982) (prepared by James McGarray) [hereinafter cited as MASS. REPORT]. Of course, budgetary and bureaucratic constraints may produce simple noncompliance with even the procedural dimensions of the statute, COURT MONITOR's REPORT, SUfFolk SUPERIOR COURT 23-25 (1982) (30 percent of Boston schools' noncompliance with court order results from failure to implement IEP requirement).

94. K. Howel, supra note 87 , at 81 (quoting Win Chadwick). 
for the implementation stage the dilemma of difference; placement and programmatic decisions receive little guidance about when to favor the "least restrictive" placement and when to find "appropriate" some more restrictive alternative, and these choices express the simultaneous concerns about making student difference matter and not matter.

Another statutory ambiguity becomes understandable in light of the difference dilemma: specifically, the statute is unclear about which children shall be included within the reach of its guarantees and this ambiguity expresses well the pros and cons of identifying difference. Given the guarantee of individual assessments and diagnoses, the Act on its face would authorize the evaluation of any and every child in a state system; given the concern to meet the needs of all children who, because of impairments, need special education, conceivably any child could claim entitlement to benefits under the Act. Yet the procedural dimensions of the EAHCA, which supply the motor and structure for the operating programs, assure protection against labeling a child as handicapped without diagnostic testing. ${ }^{95}$ These procedural dimensions express the statute's contrasting commitment to guard against the negative effects of being labeled as "different." This tension between restricting and enabling labeling actually occurs within the procedural mechanisms themselves. The procedural requirements not only guard against unjustified labeling, they also link diagnosis to entitlements: if the testing identifies special needs, the child then is entitled to an Individualized Education Plan (IEP) ${ }^{96}$ that specifies the type of services the child needs, who will provide those services, the educational objectives for the individual child, and plans to evaluate the child's progress. ${ }^{97}$ The Act further details procedural rights for the child's parents during the evaluation process, including rights to challenge educational placement decisions within the school administrative structure and ultimately before a state appellate court or federal district court. ${ }^{98}$

An evaluative study concluded that the EAHCA encourages lawsuits and gives parents and children leverage to obtain favorable settlements from school systems, but minimally affects the court workload. ${ }^{99}$ If this is the case, the procedural dimensions of the special education programs constitute a

95. 20 U.S.C. $§ 1412(5)(C)(1982)$.

96. Id. $\S 1412(4)$.

97. See id. $\$ \S 1401(19), 1412(2)-(6)$.

98. Id. $\$ 1415(\mathrm{e})(2)$. Parents also are entitled to written notice of any education decision adopted by the school, id. $\$ 1415$ (b)(1)(C); they are entitled to access to all records that the school maintains on the child, id. $\S 1415(\mathrm{~b})(1)(\mathrm{A})$; and to participate in educational decisions made by placement teams, $i d$. $\$ 1414(\mathrm{a})(\mathrm{l})(\mathrm{C})(\mathrm{iii})$. In these respects the Act implements a traditional conception of due process, complete with notice, participation and impartial review elements. Thesé procedural dimensions can also be conceived as implementing a medical model, which begins with diagnosis and evaluation, and culminates in treatment and review, with opportunities for obtaining second, and even third opinions. Cf. Minow \& Kraft, Deinstitutionalization of the Chronically Mentally Ill (Dec. 8, 1982) (unpublished manuscript). The prevalence of a medical model in the special education literature is compatible with the individualized assessment dimension of the due process framework.

99. MASS. REPORT, supra note 93, at 9-11, 27-28; see also Handler, Special Education and Cooperative Decision-Making, in The DiscretionaRY Decision (1984) (procedural rights give parents bargaining power). Some school personnel have concluded that the procedural requirements divert educators' attention from substantive educational questions. P. Hill \& D. Madey, Educational Policy Making 
major reallocation of power to parents in the assignment of educational resources and placements. The substantive dimensions of the program remain ambiguous, however, especially regarding what kind of special needs should entitle the child to special placements or services. In the context of this substantive ambiguity, the procedural mechanisms may empower parents to demand an evaluation of the child, and to pursue educational services responsive to his or her needs even where the child in previous times would not have been considered handicapped.

This hypothetical problem is a genuine issue raised by the category of "learning disabilities." Increasing recognition by educators of perceptual and psychological conditions which impair learning can be used to identify handicapping conditions of increasing numbers of students; this category of learning disabilities already includes the largest number of students served by special education. ${ }^{100}$ One expert observed that the incidence of learning disabilities in the school-aged population has been estimated as anywhere from one to ten percent, and he noted further that "[a]n outstanding elementary school principal stated to this writer that 83 percent of her center-city elementary school pupils functioned as if they were perceptually handicapped."101 Although labeling a child as handicapped can carry a stigma, categorization under the Act also carries educational benefits, and parents may seek to use this route to obtain extra services and attention for children who once would have been called slow learners. ${ }^{102}$ The attraction of labeling, then, for the purpose of getting services may produce more attribution of "difference" than before the statute, and it is not clear what the stigmatizing effects will be.

Nor is it clear what the labels mean, given these conflicting pressures to assign and to avoid assigning them. One administrator commented:

You guys at the university teach about the characteristics of $M R$ [mental retardation] as if MR is real. It may be real in a laboratory but in the classroom MR is whatever $I$ give out money for. The teachers think they are teaching kids with recognizable handicaps resulting from chromosomes or brain damage or parenting. That's a crock. . . . The kids in handicapped programs are in those programs because they made it through a chain of policy and procedure. . . . Funding procedures are the primary cause of

\footnotetext{
Through the Civil Justice System 5 (Rand Institute for Civil Justice 1983) (reporting results of study of school superintendants).

100. Division of Educational Services Special Education Programs, U.S. Dep't of Education, U.S. Office of Special Education and Rehabilitative Services, Fourth Annual Report to Congress on the Implementation of Public law 94-142: The Education for All. Handicapped Children Act 103 (1982); State Program Implementation Studies Branch, Office of Special Education and Rehabilitation Services, Second Annual Report to Congress on the Implementation of Public law 94-142: The Education for All Handicapped Children Act, 161 (1980); see also Children's Hospital-Boston, Report of Findings From the Collaborative Study of Children wrth Special Needs: Rochester City School Dist. 19 (May 1984) (learning problems cited for over 70 percent of the children).

101. Cruickshank, Myths and Realities in Leaming Disabilities, $10 \mathrm{~J}$. Learning Disabilities 51 (1977), reprinted in Educating Exceptional Children 148, 151 (Annual Editions 79/80).

102. Parents may also seek to invoke the statute to deal with a difficult child, and the result may be a battle of experts over whether the child's difficulties are due to "severe emotional disturbance" or simply "characterological" or personality traits-with services following the first label and not the second. See In the Matter of Peggy, Fairoaks County Public Schools, Hearing Officer's Decision, (May 12, 1980), reprinted in J. Shrybman, supra note 41, at 425-45.
} 
handicapping conditions. . . . The point is that a kid isn't officially handicapped unless he's labeled. The labeling process is designed to secure funding. ${ }^{103}$

The service and program benefits available through labeling alter the stigma issue, and parents or teachers may push to label a child in order to obtain extra educational resources. This phenomenon can be called "magnet labeling" and can be understood as the consequences of both increasing knowledge about and programs for learning disabled children. School systems currently struggle to develop definitions of learning disabilities to contain this demand for services and to limit the students covered by the Act, yet nothing within the Act itself provides a basis for these limitations.

Aside from the budgetary and administrative burdens posed by this struggle, the use of special education procedures to make entitlements available for more children presents a new version of the difference dilemma. Inclusion within the programs for handicapped children can bear two consequences, one for each side of the difference dilemma. Identification as handicapped entitles the child to individualized educational planning and special services, but also labels the child as handicapped and may expose the child to attributions of inferiority for this labeling with the attendant risks of stigma, isolation, and reduced self-esteem. Nonidentification frees the child from such labeling risks but also denies the child the specialized attention and services. ${ }^{104}$ As school districts encounter parents clamoring for services for their children despite the labeling problem, the procedural dimensions of the EAHCA give parents leverage to express their concern for whatever individualized attention or special programs their children can receive. The stigma issue, then, may be practically overshadowed by real benefits or effectively avoided by converting a minority of labeled, special needs kids into a growing and specially privileged category.

Thus the individualized focus and special benefits of the EAHCA offer a double-barreled version of the difference dilemma: nonidentification of a special need may result in forgone special benefits and yet identification of a special need may produce a stigmatizing label; at the same time, identification of increasing numbers of children as having special needs may overcome the risks of stigma and isolation, but by converting minority to majority, threaten the definitional and budgetary constraints on serving the handicapped. Thus, the legal framework for special education expresses the difference dilemma. The EAHCA embodies an express tension between its two substantive commitments to the "appropriate education" and to the "least restrictive alternative." This tension invokes the choice between specialized services and some degree of separate treatment on the one side and minimized labeling and minimized segregation on the other. Both substantive commitments critically depend on undisclosed delimiters that would give content to the key terms of

103. K. Howelt, supra note 87 , at $\mathbf{2 8 0 - 8 1 ~ ( e m p h a s i s ~ i n ~ o r i g i n a l ) . ~}$

104. Cf. Liebman, The Definition of Disability in Social Security and Supplemental Security Income: Drawing the Bounds of the Welfare Estates, 89 HARv. L. REv. 833, $854-55$ (1976) (denial of benefits can undermine security and status even where benefits depend on finding of total disability). 
"least," "appropriate," and "to the extent feasible." The procedural protections express both a concern to restrict stigmatizing labels and mechanisms to press for those labels as a way to secure entitlements.

The other governing statute, section 504 of the Rehabilitation Act, utilizes a straightforward ban against discrimination and does not designate which programmatic alternatives are discriminatory: does discrimination result from mainstreaming or separate classes, from identification, labeling and specialized services or nonidentification, nonlabeling, and no services? The search for answers to these open questions resurrects the difference dilemma. Are there any ways out of the dilemma? The next section identifies some possibilities, but finds them wanting.

\section{III}

\section{False Leads Out of the Difference Dilemma}

Conceptual approaches to bilingual and special education may initially suggest routes out of the difference dilemma, but that dilemma reappears even in such alternative approaches. Thus, at first it may seem fruitful to focus on the relationship between means and ends in these educational programs in order to avoid the problem of recreating difference through ignoring it or through focusing upon it. Similarly, it may at first seem useful to address frameworks for constraining the power of the school so that it does not recreate difference. Yet, upon examination, these alternatives reopen the difference dilemma, and indeed, draw connections between this problem and other problems in the legal and programmatic construction of schooling.

\section{A. Designing Means for Chosen Ends}

Finding the right means for desired ends is a familiar implementation problem in social policy. Attending to this design problem, some would argue, may be as or more important than the initial policy commitment. ${ }^{105}$ Some means/ends problems take the general form of unintended consequences from chosen means that may undermine desired ends. Indeed, a standard criticism of schools emphasizes the lack of fit between the means

105. See, e.g., J. Pressman \& A. Wildasky, Implementation (1973); E. Quade, Analysis for Public Decisions 259-63 (1975). Here, the design problem refers to the selection of strategies in the initial design of the program rather than the mastery of political, organizational, and psychological constraints and resistences to change. For effective studies of this latter concern with implementation, see Clune \& Van Pelt, A Political Method of Evaluating the EAHCA and the Several Gaps of Gap Analysis, LAW \& Contemp. Probs., Winter 1985, at 7 (implementation of special education programs affected by political adjustment among competing interests); Kuriloff, Is Justice Served by Due Process?: Affecting the Outcome of Special Education Hearings in Pennsylvania, LAw \& ConTemp. Probs., Winter 1985, at 89; Neal \& Kirp, The Allure of Legalization Reconsidered: The Case of Special Education, LAw \& CoNTEMP. Probs., Winter 1985, at 63; Weatherly \& Lipsky, Street-Level Bureaucrats and Institutional Innovation: Implementing Special-Education Reform, $47 \mathrm{HARv.} \mathrm{EDUC.} \mathrm{Rev.} 171$ (1977). The particular concern here is instead with the choice between program designs aimed at creating enclaves different from the dominant community and programs aimed at reflecting the dominant community. See infra notes 108-33 and accompanying text. 
schools use and the ends they seek. John Holt dramatizes this criticism while telling of the student who handed in the ink copy of her written composition:

Our rule is that on the ink copy there must be no more than three mistakes per page, or the page must be copied again. I checked her paper, and on the first page found five mistakes. I showed them to her, and told her, as gently as I could, that she had to copy it again, and urged her to be more careful-typical teacher's advice. She looked at me, heaved a sigh, and went back to her desk. She is left-handed, and doesn't manage a pen very well. I could see her frowning with concentration as she worked and struggled. Back she came after a while with the second copy. This time the first page had seven mistakes, and the handwriting was noticeably worse. I told her to copy it again. Another bigger sigh, and she went back to her desk. In time the third copy arrived, looking much worse than the second, and with even more mistakes. ${ }^{106}$

On reflection, Holt commented,

In schools-but where isn't it so?-we so easily fall into the same trap: the means to an end becomes an end in itself. I had on my hands this three-mistake rule meant to serve the ends of careful work and neat compositions. By applying it rigidly was I getting more careful work and neater compositions? No; I was getting a child who was so worried about having to recopy her paper that she could not concentrate on doing it, and hence did it worse and worse, and would probably do the next papers badly as well. 107

The connections between means and ends in bilingual and special education are more complicated than the governing statutes imply. The laws governing both bilingual and special education rely at key points on undefined terms, such as "appropriate," "to the maximum extent feasible," "to the extent necessary," and "to progress effectively." Such terms on their face imply that there are known or uncontroversial connections between the means called for by the law and the ends endorsed by it-or that reasonable decisionmakers could agree about what means will be appropriate, necessary, and so forth. Of course, it is more likely that legislators and judges adopt such terms to hold off for another day debates over the meaning of such delimiters. The question of how to connect means to ends in bilingual and special education, not surprisingly, triggers renewed controversy. But it may be surprising to see the difference dilemma reappearing in these controversies.

1. The Design Dilemma and Bilingual Education. The problem of connecting means to ends was left open in Lau v. Nichols: 108 what programs should be designed to remedy the functional exclusion of students without English proficiency in regular classes taught in English? This design problem is especially tricky for two reasons. First, the term "exclusion" appeared in the governing civil rights statute framed with racial segregation in mind, ${ }^{109}$ but the "exclusion" of the non-English-proficient students was not due to segregation, but to the lack of fit between the school program and the students' own backgrounds. The remedy obviously could not simply be to integrate such stu-

106. J. Holt, How Children Fail 133-34 (1964).

107. $I d$.

108. 414 U.S. 563, 564-65 (1974); see supra text accompanying notes 48-52.

109. Civil Rights Act of 1964, $\$ 601,78$ Stat. 252 (codified at 42 U.S.C. $\S 2000 d$ (1982)). 
dents into existing classrooms, for it was in such classrooms that these students were effectively excluded from the educational benefits.

Secondly, and also growing from experience with racial segregation of school children, the concern for student self-esteem as a key element in equal educational opportunity complicates the design of bilingual programs. As one observer of the federal legislative process on the subject observed:

Arguments about the degree to which assimilation process assaulted a child's sense of self-worth led in one programmatic direction, while contentions about the Hispanic level of academic achievement and school dropout rate, ${ }^{[110]}$ had they been the most compelling, would have led in quite another. That is, concern solely about the academic record of children of limited-English-speaking ability would have led to unequivocal support for the establishment of transitional programs aimed at giving those children an equal educational start. But concern about the psychological harm of forced assimilation lent legitimacy to the establishment of programs which aimed to promote not scholastic achievement but a greater sense of self-worth by means of linguistic and cultural maintenance. They lent legitimacy to schools within schools, to ethnic educational enclaves run for and by ethnic groups. ${ }^{111}$

It is important to clarify that the concern for students' senses of self-worth marks debates over the means, not the ends, of schooling. Few if any supporters of bilingual-bicultural education dispute that a major goal of such programs is to develop the students' proficiency in English. ${ }^{112}$ To some extent, the choice among different types of means to achieve this end may be resolved with reference to empirical studies of the effectiveness of contrasting programs. But such studies are currently inconclusive, and the debate focuses not on effectiveness but on the issue of stigmatizing cultural difference. ${ }^{113}$

The design problem thus juxtaposes preoccupation with English-language proficiency against preoccupation with creating environments within schools that are more hospitable to children who feel alien there. The first preoccupation would focus on academic skills and English language acquisition; the second would address the cultural contrasts between child and school. Designing programs solely responsive to either one of these concerns could exacerbate the children's educational problems. ${ }^{14}$ The difference dilemma, in short, reappears at this point: how to address the needs of students who

110. Much of the debate over bilingual education focuses on the Hispanic experience.

111. Implications of Bilingualism: Education, in The New Bilingualism: AN American Dilemma 155-56 (M. Ridge ed. 1981) (quoting Abigail Thernstrom) (proceedings of a conference sponsored by the Center for Study of the American Experience, The Annenberg School of Communications, University of Southern California, May 1980).

112. See Lanier, Teaching with Subtitles, ChI. MAG., June 1984, at 163.

113. There are unresolved debates over the effectiveness of different programs simply in terms of producing English proficiency. See L. Baca \& H. Cervantes, The Bilingual Special Education INTERFACE 332-33 (1984) (reviewing debate over effectiveness of bilingual programs); Baker \& de Kanter, supra note 56, at 33 (reviewing studies); Carpenter-Huffman \& Samulon, supra note 56, at $141,147,169$ (students in self-contained classrooms at the elementary level receive more languageassistance instruction than children in pull-out programs). The debate at this point occurs even at the level of social science measures. See A. Cohen, M. Bruck, F. Rodriguez-Brown, Bilingual EduCation Series 6 (Center for Applied Linguistics 1982) (methodological debates).

114. Compare Serna v. Portales Mun. Schools, 499 F.2d 1147, 1150 (10th Cir. 1974) (" [New Mexico teacher] testified that 'until a child developed a good self image not even teaching English as a second language would be successful. If a child can be made to feel worthwhile in school then he will learn even with a poor English program'.") with Glazer, Pluralism and Ethnicity, in THE NEw BILIN- 
are considered different without stigmatizing them or undermining their identity becomes a salient concern in crafting programs for children whose primary language is not English.

This link between the difference dilemma and the problem of designing means and ends in bilingual education is highlighted by two early bilingual cases which made use of intelligence testing (IQ scores) to arrive at contrasting conceptions of how to implement the mandate of bilingual education. In Serma v. Portales Municipal Schools, ${ }^{115}$ the district court found that IQ test scores for Spanish-surnamed children were different from those of the "average" child in the same school system."16 The court concluded that, compared with the performance of the other students, the performance of the Spanish-surnamed children was not what it should have been. The court added that "[c]oupled with the testimony of educational experts regarding the negative impact upon Spanish-surnamed children when they are placed in a school atmosphere which does not adequately reflect the educational needs of this minority," the evidence established a legal violation. ${ }^{117}$ In affirming, the Court of Appeals for the Tenth Circuit observed that "[i]ntelligence quotient tests show that Lindsey students fall further behind as they move from the first to the fifth grade." 118 The district court ordered a curriculum plan to implement bilingual training and bicultural outlook programs and also directed that a special effort be made to recruit and hire bilingual teachers. 119

In contrast, in Otero v. Mesa County Valley School District No. 51, 120 the district court accepted the school department's theory that differentials in student abilities, rather than linguistic deficiencies, explained the educational problems of Mexican-American students. ${ }^{121}$ The court then rejected the plaintiffs' claim that poor school performance by Chicano students occurs because the school district

has created a school system oriented for middle class Anglo children, has staffed that system with non-Chicano personnel who do not understand and cannot relate with Chicano students who are linguistically and culturally different, to the extent that the Chicano students and their parents do not feel that School District 51 is "their" school. ${ }^{122}$

cualism: An American Dilemma 55, 62-63 (M. Ridge ed. 1981) (pragmatic advantages to assimilation, given public school control of access to higher education).

115. 351 F. Supp. 1279 (D.N.M. 1972), affd, 499 F.2d 1147 (10th Cir. 1974).

116. Id. at 1281-82.

117. Id. at 1282. The district court relied on the equal protection clause of the Constitution. Id. The court of appeals affirmed, but relied on Lau v. Nichols. See 499 F.2d at 1153.

118. 499 F.2d at 1150.

119. Serna v. Portales Mun. Schools, 351 F. Supp. 1279, 1283 (D.N.M. 1972), affd, 499 F.2d 1147, 1154 (10th Cir. 1974) (expressing approval of district courts' plan).

120. 408 F. Supp. 162 (D. Colo. 1975), remanded, 568 F.2d 1312 (10th Cir. 1977), on remand, 470 F. Supp. 326 (D. Colo. 1979), affd, 628 F.2d 1271 (10th Cir. 1980). A useful case study of the suit appears in M. Rebell \& A. Block, Educational Policy Making and the Courts: An Empirical Study of Judicial Activism 147-74 (1982).

121. M. REbell \& A. Block, supra note 120, at 162-63, 173-74. The case study explains more explicitly than does the opinion itself the use of IQ tests. The court also relied on achievement tests, and on studies of the use of Spanish in the students' homes. 408 F. Supp. at 165-66.

122. Plaintiff' Opening Statement, quoted in Otero, 408 F. Supp. 162, 164 (D. Colo. 1975). Plantiffs also explained that their case would show that "[t]he cultural and linguistic makeup of Chi- 
The district court rejected the plaintiffs' request for bilingual-bicultural instruction ${ }^{123}$ and the hiring of more bilingual teachers. ${ }^{124}$ The court concluded that relatively few students had no English proficiency, and the transitional English instruction already offered them by the school district was an adequate means for dealing with any legal obligation the school had to eliminate inequality. ${ }^{125}$ Thus, the Otero court relied on IQ tests-the very measure used in Serna to identify a language barrier requiring a remedy-to rule out the need to remedy a language barrier. ${ }^{126}$

What explains this inconsistent use of IQ scores? What different conceptions of the remedy for inequality may be at work here? In Serna, the scores are treated as "outcome" measures, capturing the effect of schooling and therefore measuring what happens when schools make the error of ignoring student difference. According to this view, the school systems' failure to create an environment hospitable to the different cultural, ethnic, and language experiences of the Spanish-surnamed children produced the discrepancy in IQ scores and justified the remedy of bilingual and bicultural programming, as well as the hiring of bilingual teachers. Here, then, liability is founded on the error of ignoring difference where it exists.

Otero, in contrast, used the IQ scores without assuming any pre-existing difference between Mexican-American students and other students. The difference in their IQ scores, then, could be used to explain their different experiences in school, and to rule out the claim for curricular and staff changes to address the identity and self-esteem of the Mexican-American studies. This use of the IQ scores relied on a conception of the right means to achieve the ends of bilingual education: the right means should alter the educational system as little as possible, and deploy short-term intensive English instruction for the few students unable to function in the mainstream classroom.

cano students has posed an educational incompatibility between District 51 's educational program and the learning style of these students to the degree that they do not effectively and equally benefit from the school's program as compared to Anglo students." Id. at 163-64.

123. The court may have been influenced by the Tenth Circuit's decision in Keyes v. School Dist. No. 1, 521 F.2d 465, 480 (10th Cir. 1975), cert. denied, 423 U.S. 1066 (1976), which rejected a bilingual education plan designed by the same expert used in Otero; both the appellate court in Keyes and the district court in Otero emphasized the importance of state and local control rather than judicial intervention for dealing with the problem of minority students. See id. at 482; Otero, 408 F. Supp. at 171-72; see also Teitelbaum \& Hiller, Bilingual Education: The Legal Mandate, 47 HaRv. Educ. REv. 138, 151 (1977) (discussing Keyes and Otero.)

124. Plaintiffs argued that the school district's hiring practices produced an environment alien to the Chicano children; plaintiffs couched their claim as an employment discrimination issue. The district court initially rejected plaintiffs' employment discrimination claim on the grounds that they lacked standing to assert it; on remand from the court of appeals, the district court concluded that the plaintiffs failed to establish discriminatory intent in the school district's employment practices, and also accepted the school board's nondiscriminatory reasons for statistical evidence of discrimination against Chicano job applicants. Otero v. Mesa County Valley School Dist. No. 51, 470 F. Supp. 326, 327 (D. Colo. 1979), affd, 628 F.2d 1271 (10th Cir. 1980).

125. 408 F. Supp. at 168-70. Plaintiffs' claims were couched in constitutional terms; the court found no constitutional violation and compliance with state and federal statutes.

126. The Otero court similarly relied on standardized English proficiency tests, 408 F. Supp. at 165-66. 
The link between the use of the IQ scores and the implicit choice of means for bilingual education becomes apparent in critiques of this testing method. These critiques further expose the difference dilemma, even at this level of technical debate about testing. The Otero court's reliance on IQ scores could be challenged for failure to acknowledge the cultural and linguistic bias of the tests themselves. ${ }^{127}$ In a sense, relying on tests of "intelligence" to explain why students without English proficiency perform less well in school than other students confirms a tautology, because intelligence is defined in terms of mastery of English language skills. Some commentators have observed that the math scores of Chicano students more closely approximate the scores of Anglo students; this implies that the greater disparity in the language arts scores reflects difficulty with the verbal content of the tests. ${ }^{128}$ Thus, it is possible to criticize the Otero court for its failure to understand how ignoring preexisting differences can recreate them.

It is equally important, however, to consider the other side of the difference dilemma: does focusing on difference also re-establish it? In particular, starting with the premise that IQ tests do not test innate ability, the tests nonetheless may accurately identify those students who are not likely to do well in the classroom designed for Anglo children. ${ }^{129}$ So long as those measures of classroom success are not being challenged as discriminatory, disparities in the IQ scores support educational programming geared toward those traditional classroom success measures, not toward the language and cultural identities of Mexican-American children. ${ }^{130}$

Thus, the Otero court may well have applied a tautology by using IQ scores to explain the school problems of Mexican-American students, but the design of means to solve the discrimination problem must take into account the real likelihood that the same Anglo measures of success will be applied to the Mexican-American children at each point throughout the school system, and

127. To the extent that plaintiffs raised this issue at trial, it was rebutted by the defense expert who claimed his methodology compensated for any alleged bias. M. REBELL \& A. BLOCK, supra note 120 , at 163-64.

128. M. ReBell \& A. BLOCK, supra note 120, at 163-64; $c$. Hobson v. Hansen, 269 F. Supp. 401 (D.D.C. 1967), affd in part and appeal dismissed in part, sub nom. Smuck v. Hobson, 408 F.2d 175 (D.C. Cir. 1969) (en banc) (rejecting use of scholastic aptitude tests in assigning students to tracks due to racial and socio-economic impact); Light \& Smith, Social Allocation Models of Intelligence: A Methodological Inquiry, 39 Harv. Educ. Rev. 484 (1969) (bias problems in intelligence testing). See generally S. Gould, The Mismeasure of MAN (1981) (racial, class, and sex bias historically expressed in theories and testing of intelligence); Kirp, Schools as Sorters: The Constitutional and Policy Implications of Student Classification, 121 U. PA. L. REv. 705, 726-30 (1973) (reviewing research on student classification).

129. See Blatt \& Garfunkel, Psycho-Educational Assessment, Curriculum Development, and Clinical Research with the 'Different Child', in AN Alternative TextBook in SPECIAL Education 277, 288 (1977) (IQ as good predictor of academic success, and generally used as such); Goodman, De Facto School Segregation: A Constilutional and Empirical Analysis, 60 CALIF. L. Rev. 275, 434-35 (1972) (IQ tests reflect endowment and experience and accurately identify those students unlikely to do well in mainstream classroom).

130. Success measures that vary from the traditional ones need not undercut the commitment to English proficiency. See supra note 112 and accompanying text (discussing importance of learning English to supporters of bilingual-bicultural education). 
beyond. English language and American culture will continue to measure the students' success and future opportunities. Nathan Glazer put it this way:

One will never do as well in the United States living in Spanish, or French, or Yiddish, or Chinese, as one will do living, learning, and working in English. . . . [it] is therefore a naive argument to say that putting bilingual/bicultural education into the public school curriculum will make a significant difference in affecting the general respect in which a given culture and language are held. ${ }^{131}$

Failing to acknowledge the way in which all children in this sense are similarly situated to the school criteria for success could produce programming that reinforces the differences of the already stigmatized groups. The two sides of the difference dilemma, accordingly, may take on competing conceptions of means and ends. Should we create an enclave of Chicano language and culture within the school to bolster the student's self-esteem and ability to perform well in school? The enclave would include more teachers with a background in the language and culture, and more curricular attention to and acknowledgment of that cultural identity, even in the development of Englishlanguage skills. Or should we instead create limited, transitional programs to give Chicano students basic language skills and then incorporate them as soon as possible within the classroom designed for the rest of the students?

Arguments for and against replicating the larger community within the school as the best means of preparation are met by arguments for and against creating an alternative, tailored environment within the school to support individual student development. Replicating the larger social order within the school would involve creating the school as a community where English is the dominant language and proficiency in it is not only expected, but is sought through immersion or intensive instruction; the medium is the message, and the school's own commitment to English as the dominant language is expressed through its required use of English in the classroom, hallways, and life of the school. There are problems with this approach, however. It may actually not produce English proficiency among non-English native speakers. ${ }^{132}$ It may undermine such students by depriving them of a sense of self-respect and identification with school culture. Imposing a dominant English approach in the school may reproduce the patterns of economic and social inequality which are present in the outside community rather than offering an enclave away from those hierarchies. Such an enclave would be a safe terrain where each child would have a chance to succeed.

Constructing the school as an enclave, in contrast, would deploy bilingualbicultural programs designed to create the same combination of comfort with the familiar and introduction to the unfamiliar that the majority-language student typically encounters in public school. ${ }^{133}$ This approach, however, could

131. Glazer, supra note 114 , at 55,63 .

132. See supra note 113 and accompanying text (discussing studies of effectiveness of different programs).

133. Many excellent schools are viewed by their staff and students as enclaves of one sort or another. See S. Lightfoot, The Good High School: Portraits of Character and Culture 321 22 (1983) (discussing Milton academy and parochial schools); of. Cover, The Supreme Court, 1982 
impede the minority-language child's fluency in English. It might also shore up values and attitudes that compete with the culture dominant in the larger community and create painful ambivalence in the child.

The tension over means, then, may reveal genuine underlying tension over the ends of schooling. Some wish to use the school to transform the society so that different kinds of adults can function or succeed within it, not just to transform the individual child into an adult capable of functioning in that society. Clarity or unanimity on goals would not resolve the means/ends dilemma. Designing the best preparation for a child entering any given vision of the larger community still involves the dilemma of choice between replicating that vision in the school design, or designing some other protective environment. Which route gives the child better opportunities for growth, development of skills, and the equipment for success in whatever society will greet her or him?

2. The Design Dilemma and Special Education. As with bilingual education, education for the handicapped could take the form of giving special students experience with an unaccommodating, untransformed world-minimizing special treatment, mixing students with special needs in with other students, and exposing each group to one another as they would be outside the school. Alternatively, the school can be designed to include measures tailored for the handicapped child, ranging from specialized instruction within the mainstream classroom to separate classrooms or individualized schooling and evaluations. Both routes run the risk of not preparing the child with special needs for the waiting world. ${ }^{134}$

The case of Amy Rowley, which was reviewed by the Supreme Court, ${ }^{135}$ illustrates this problem. The case presented the Court with the following statutory interpretation questions: What is the meaning of the EAHCA term "free appropriate public education", and what means would achieve the ends of the Act to give content to the term "appropriate"? The Court concluded that challenges to a school placement brought under this statutory requirement should be assessed according to whether (a) the state complied with the procedures established in the statute, ${ }^{136}$ and (b) "the individualized educational program developed through the Act's procedures [is] reasonably calculated to enable the child to receive educational benefits."197

Behind this language was the problem of devising an educational program for Amy Rowley, a prelingually deaf child who attended regular classrooms from kindergarten on. The individual educational plan developed by the

\footnotetext{
Term-Foreword: NOMOS and Narrative, 97 HARv. L. REv. 4, 31 -33 (1983) (subgroup may develop a normative world and seek associational rights for self-realization in normative terms).

134. See J. Handere, The Discretionary Decision 34 (1984).

135. Board of Educ. v. Rowley, 458 U.S. 176 (1982).

136. Id. at 207.

137. Id. at 206-07. The Court emphasized the nature of the Act as a grant with conditions agreed upon by participating states, and that if the state has complied with the obligations imposed by Congress "the courts can require no more." Id. at 207.
} 
school while Amy attended first grade provided that her education should be supplemented by instruction from a tutor one hour each day and from a speech therapist for three hours a week. ${ }^{138}$ Amy's parents objected that this plan failed to provide an "appropriate" education; they believed that she should also be provided with a qualified sign language interpreter in all of her classes. The school countered that Amy did not need such an interpreter because she was "achieving educationally, academically, and socially" without such assistance. Her parents maintained that without an interpreter, Amy understood a maximum of fifty-eight to fifty-nine percent of oral communications, but with an interpreter, her comprehension of oral communication was 100 percent. $^{139}$

Obviously, a major difference in cost to the school would follow from the positions taken by the school officials and by the child's parents. In addition, their positions reflected contrasting concepts of the means to achieve the ends of her education. The school's position looked to the child's achievement and, as endorsed by the Supreme Court, asked whether the educational program was designed by the school to enable the child to receive educational benefits. Because Amy's achievement levels were above average, and she was easily able to advance from grade to grade in mainstream classrooms, the school and the Court concluded that her educational program was appropriate. ${ }^{140}$ The parents, in contrast, were committed to a method of communication for the deaf called "total communication," which involved not only lip reading and speech development, but also sign language, fingerspelling, touching, and visual cues. ${ }^{141}$ Without such complete assistance, they maintained, she was not provided the same opportunity as other children to receive oral communications in the classroom, or to succeed in life. ${ }^{142}$

Fundamentally, the parents wanted to create a special environment for Amy that would adjust fully for her disability and use the special measure of a sign-language interpreter to provide as much of the educational "inputs" as the school provided other students, although it would be unlikely that the child would have a sign language interpreter with her for the rest of her life. The school wanted to provide educational services which would allow Amy to function and achieve in the classroom setting and develop her self-sufficiency, meaning self-sufficiency in a world not likely to accommodate her special needs. ${ }^{143}$

138. Id. at 184. The plan also provided for use of an FM hearing aid which could amplify words spoken into a receiver. Amy had the ability to hear sounds in low frequencies, and very diminished ability to hear sounds in the frequencies of human speech. Brief for Respondents, at 11-12.

139. The Rowleys relied on tests administered by a speech and hearing expert for these percentages. Rowley v. Board of Educ., 483 F. Supp. 528, 532 (S.D.N.Y. 1980), affd, 632 F.2d 945 (2d Cir. 1980), rev'd, 458 U.S. 176 (1982).

140. Board of Educ. v. Rowley, 458 U.S. 176, 209-10 (1982).

141. Brief for Respondents, at 2-3.

142. Id. at $10-11,20$.

143. See Brief for Petitioners, at 66 (discussing legislative history of EAHCA). In further contrast, the district court had reasoned that an "appropriate education" meant an opportunity for each handicapped child "to achieve his full potential commensurate with the opportunity provided to other children," Rowley v. Board of Educ., 483 F. Supp. 528, 534 (S.D.N.Y. 1980); thus the shortfall 
Amy Rowley's situation does not seem so dire because, as a gifted child, she was able to perform adequately within the terms set by the mainstream classroom. Nonetheless, the conflicting conceptions of her educational alternatives highlight the risks of each possible means of educating her: without an interpreter she would miss some of the educational opportunities afforded her classmates, and, as a result, miss the chance to develop as fully as she might; but with an interpreter she would not be forced to develop the ability to function well without support in preparation for the day when such support would be unavailable.

In response to these kinds of risks for other children with special needs, some experts emphasize educational services for handicapped students which are specifically designed to help them become competent in daily adult life. ${ }^{144}$ Another strategy would supplement the special needs student's experience in the mainstream classroom with sign language interpretation, special learning materials, or weekly tutoring. ${ }^{145}$ Different educational strategies have emerged for severely and mildly handicapped children, but risks remain for any child with either technique: the student may be stigmatized by specialized instruction, ${ }^{146}$ or subjected to a self-confirming labeling process. ${ }^{147}$ It is also possible that the student may be burdened by special services. ${ }^{148}$ The student

from the handicapped students' potential should not be greater than the shortfall from the nonhandicapped students' potential in their educational achievement. The difficulties in measuring either student potential or the shortfall from it doomed this standard, even though it acknowledged the possibility that Amy Rowley's school achievements despite her handicap reflected potential for even greater achievement.

144. I. Amary, The Rights of the Mentally Retarded-Developmentally Disabled to TreatMENT AND EDUCATION 71 (1980) (urging social relations, personal grooming, personal safety, and transportation curriculum for developmentally disabled).

145. See J. HANDLER, supra note 134, at 3-4, 9-10 (special education programs supplementing classroom instruction with remedial help, resource rooms, and consulting experts). Massachusetts, for example, developed ten "prototype" placements based on the degree to which modifications of the mainstream classroom program are made. Thus, the prototypes are: (1) regular classroom instruction with some modifications; (2) an educational program at the regular school with no more than 25 percent of the time spent in special education classes; (3) an educational program at the regular school with no more than 60 percent of the time in special education classes; (4) a special class placement within the regular school setting but mostly separate from the regular educational programming; (5) a special private day school program; (6) teaching or treatment at home or (7) in a hospital; (8) occupational training in a public school; (9) teaching or treatment in a residential school; and (10) combinations of the previous possibilities. See Massachusetts Advocacr Center, Making School Work: An Education Handbook for Students, Parent and Professionals 48 (rev. ed. 1975); see also J. Shrybman, supra note 41, at 26-129 (describing continuum of educational services ranging from least to most restrictive).

146. Kirp, Buss \& Kuriloff, supra note 46 , at 45-46.

147. See Bogdan \& Taylor, The Judged, Not the Judges: An Insider's View of Mental Retardation, in AN Alternative Textbook in Special Education 217, 228, 230-31 (1977) (mentally retarded individual describes impact of label on his sense of his own abilities). This problem may be particularly acute for the doubly different child who is a member of both a racial or ethnic minority and a handicapped or special education subgroup: "When a child from a deprived background is treated as if he is uneducable because he has a low test score, he becomes uneducable and the low test score is thereby reinforced." Hobson v. Hansen 269 F. Supp. 401, 484 (D.D.C. 1967) (quoting Kenneth Clark).

148. One child reportedly progessed better academically and socially when psychological services and tutoring were suspended and the academic lessons were programmed for his level and graded less strictly. Sarason, Levine, Goldenberg, Cherlin \& Bennett, Trarslating Psychological Concepts into Action, in An Alternative Textbook in Special Education 233, 252-53 (1977). 
may also fail to learn how to function effectively outside the setting of a specially designed school. Consider this episode: An instructor in a residential school for blind children points out the mantel of a fireplace to a child who is about to bang his head on it. The child says, "Why don't you put some padding on it? This is a school for the blind, we could hurt ourselves." The instructor replies, "There won't be padding outside the school when you leave here."149 Not padding the mantelpiece at the school for the blind may train the blind students to be wary about such hazards; it may also permit accidents within the school.

Nevertheless, designing programs that do not tailor the school environment or educational plans to the special needs of the students could similarly perpetuate their disabilities. The student may fail to develop the ability to function, with or without special assistance. Also, integration into a mainstream classroom may produce less sensitivity to individual student needs. ${ }^{150}$ In this light, some thoughtful observers have urged that classification and placement decisions should explicitly address "facts concerning possible disadvantages resulting from special classification" as well as student needs and school system resources. ${ }^{151}$ The risks of stigmatization from special services and continual reliance on special assistance arise if negative attitudes toward handicaps persist in the larger community, and if the adult worlds of employment, housing, and transportation fail to accommodate people with special needs. Yet the dilemma of how best to achieve preparation for adulthood remains, whatever vision of the evolving society underlies the means selected.

3. Designing Means and Ends: Minorities and the Difference Dilemma. The following episodes further illustrate the design problem in the treatment of varied minority groups by educational institutions:

-In an all-black urban school, one teacher advises another not to bring up slavery while discussing the cotton gin. She said, without malice and only with an expression of the most intense and honest affection for the children in the class: " 'I don't want these children to have to think back on this year later on and to have to remember that we were the ones who told them they were Negro.','152

149. An exchange like this occurs in a children's book about a boy who becomes blind. J. GARField, Follow My Leader (1957); see also Unwanted Help, N.Y. Times, Sept. 16, 1984, at 49, col. 1 (Association for the Blind oppose university developed electronic guidance system because the system would discourage blind students from developing their own senses).

150. Blatt, The Integration-Segregation Issue: Some Questions, Assumptions, and Facts, in An ALternAtive Textbook in Special Education 128-29 (1977) (describing this view and lack of evidence on either side).

151. Kirp, Buss \& Kuriloff, supra note 46, at 137.

152. J. Kozol, Death at an Early Age: The Destruction of the Hearts and Minds of Negro Children in the Boston Public Schools 68 (1968). Kozol continues:

The amount of difficulty involved in telling children they are Negro, of course, is proportional to the degree of ugliness which is attached to that word within a person's mind . . . What she was afraid of was to be remembered as the one who told them that they were what they are . . . . To be taught by a teacher who felt that it would be wrong to let them know it must have left a silent and deeply working scar. The extension to children of the fears and evasions of a teacher is probably not very uncommon, and at times the harm it does is probably trivial. But when it 
-A rehabilitation program for drug addicts creates a supportive, structured residential setting, emphasizing honesty, affection, consistency, and respect for self and others. Students in the program develop skills in honest communication, empathy, and collaboration. On entering the workplace, the students discover that these skills are not rewarded and may even hinder success. Frank conversation and cooperative concern for others collide with workplace values separating public and private life and emphasizing competition and individual success. Moreover, taking cues from others at the workplace, the program's students resort back to escapist and destructive ways of dealing with their emotions-such as drug use. ${ }^{153}$

As these episodes suggest, constructing an environment to prepare students for success outside of it poses risks of failure within the training environment and failure outside of it. Steps to avoid failure within the learning environment may increase chances of failure outside, but recreating the outside environment for the purpose of training increases the risks inside. Not confronting race issues within the school may protect the students from some discomfort during the school hours, but will not prepare them for the hostility about race they will encounter outside the school. Creating an alternative environment of support and honesty within a drug rehabilitation program may strengthen participants so that they can enter the job world, but their new-found strength may depend on support and honesty which is absent and even rejected at the workplace.

Shielding a minority child from community dislike may allow her to develop a sense of self-esteem but disable her from recognizing hostility when it comes her way. In her autobiography, the black poet Audre Lorde recalls racial tension on the streets of New York when she was growing up:

\begin{abstract}
As a very little girl, I remember shrinking from a particular sound, a hoarsely sharp, guttural rasp, because it often meant a nasty glob of grey spittle upon my coat or shoe an instant later. My mother wiped it off with the little pieces of newspaper she always carried in her purse. Sometimes she fussed about low-class people who had no better sense nor manners than to spit into the wind no matter where they went, impressing upon me that this humiliation was totally random. It never occurred to me to doubt her. It was not until years later once in conversation I said to her: "Have you noticed people don't spit into the wind so much the way they used to?" And the look on my mother's face told me that I had blundered into one of those secret places of pain that must never be spoken of again. ${ }^{154}$
\end{abstract}

Professor Catherine Mackinnon commented on this incident: "Which is worse: to protect the child from knowing that she is the object of degradation by some members of the community, or to alert her and prepare her to deal with that attitude when it comes her way?" 155 But these problems arise not

comes to a matter of denying to a class of children the color of their skin and of the very word that designates them, then I think that it takes on the proportions of a madness.

Id. at 68-69 (emphasis in original).

153. Bookbinder, Educational Goals and Schooling in a Therapeutic Community, 45 Harv. Educ. Rev. $71,80-83$ (1975).

154. A. Lorde, Zami: A New Spelling of my Name 17-18 (1982).

155. Lecture by Professor Catherine MacKinnon at Harvard Law School (January 1983). Of course, experience with community hostility may itself be the best educator, but this too could work 
just for children who are in some way different from other children. The means/ends problem, and its relation to the dilemma of difference, recurs in more general questions about treating all children, as the following examples of first amendment issues in public schools indicate.

4. The First Amendment and Schooling. In the context of free speech and freedom of expression issues, the courts rely on a view of the school's mission as preparing students for participation in a political community committed to freedom of expression and wide ranging exchange of views. The courts, however, also embrace a view of the school's special function, clientele, and problems that may be incompatible with free expression and a wide ranging exchange of views within the school itself. Judicial ambivalence about the reach of first amendment protections within the school displays the dilemma over how to design the means of schooling to advance its ends. Thus, the Supreme Court has declared that students do not "shed their constitutional rights to freedom of speech . . . at the schoolhouse gate," 156 and " $t \mathrm{t}]$ he classroom is peculiarly the "marketplace of ideas'."157 According to this view, there is an identity between means and ends; "[ $t$ ]hat [school boards] are educating the young for citizenship is reason for scrupulous protection of Constitutional freedoms of the individual, if we are not to strangle the free mind at its source and teach youth to discount important principles of our government as mere platitudes." 158

At the same time, the Supreme Court has expressed solicitude for the special vulnerabilities of children and the "special characteristics of the school environment."159 According to this view, schools should be authorized to socialize young people, to inculcate habits of good citizenship and values associated with the democratic political system. Free expression issues should be treated differently in the schools than in the larger community; student and teacher speech may need to be restricted, curricula may be constructed to select ideas and values to accomplish the task of socialization. The means, then, for preparing young people to participate in the open debate in the adult community could recreate the same open debate in the schools or arrange a more restricted and controlled exchange of ideas framed by the

the other way. This issue has arisen in the context of challenges to the custody of a child by a lesbian mother; some argue that the experience of community intolerance will injure the child. E.g., Townend v. Townend, 1 Fam. L. ReP. (BNA) 2830, 2831 (Ohio Ct. Com. Pleas, 1975). Others suggest that the experience itself could strengthen the children:

It is just as reasonable to expect that they will emerge better equipped to search out their own standards of right and wrong, better able to perceive that the majority is not always correct in its moral judgments, and better able to understand the importance of conforming their beliefs to the requirements of reason and tested knowledge, not the constraints of currently popular sentiment or prejudice.

M.P. v. S.P., 169 N.J. Super. 425, 438, 404 A.2d 1256, 1263 (1979).

156. Tinker v. Des Moines Indep. Community School Dist., 393 U.S. 503, 506 (1969).

157. Keyishian v. Board of Regents, 385 U.S. 589, 603 (1967).

158. West Virginia State Bd. of Educ. v. Barnette, 319 U.S. 624, 637 (1943).

159. See Board of Educ. v. Pico, 457 U.S. 853, 868 (1982) (opinion of Justice Brennan) (quoting Tinker); Tinker v. Des Moines Indep. Community School Dist., 393 U.S. 503, 506 (1969). 
school officials and guarding against disorder within the school. ${ }^{160}$ The judiciary wants to allow school officials to arrange a protected environment and yet it also wants to avoid the apparent restrictions on first amendment activities within the school that this protected enclave notion would implement.

The Supreme Court's consideration of this subject in Board of Education $v$. Pico, ${ }^{161}$ reveals persistent disagreement on these issues; the seven separate opinions diverge on this means/ends question. Some members of the Court seem to endorse the view that the better means for preparing students for the adult community is to have them experience the marketplace of ideas in the school setting; other members of the Court favor inculcation of norms and values by the school in a setting protected from expression which school boards find objectionable. ${ }^{162}$

This first amendment problem suggests the complications in devising means to ends in schooling; creating a sheltered environment may not prepare students to handle the range of expression they will encounter as adults, but students may not be ready to handle some expression permitted in the adult world. In a sense, then, the problem of schooling is itself a problem of designing means for the end of preparing students for what awaits them. The creation of either an enclave or a microcosm of the awaiting world carries risks. This problem of design derives from the dilemma of difference: it is because children are considered different from adults that the need for a special environment arises, but it is because they are also not to be excluded ultimately from the world of adults that they need some experience with the world awaiting them. The problem highlights ambivalent attitudes about whether children are already more like or more unlike adults with respect to either their abilities to handle free expression or their entitlement to enjoy and learn from it. They are, at the same time, different and similar to us, and on the route to becoming like us.

Conceiving of children as potential adults does not resolve the ambivalence because this conception could support either denying children the free expression rights of adults until they become adults, or granting children those rights in deference to what they will become. A child's potential to become like an adult may seem less problematic than the potential of the

160. See Tinker v. Des Moines Indep. Community School Dist., 393 U.S. 503, 509, 524 (1969) (Black, J., dissenting) (modify first amendment protections in light of risks of school disruption).

161. 457 U.S. 853 (1982).

162. Compare id. at 863-68 (opinion of Justice Brennan, joined by Justice Marshall and Justice Stevens) with id. at 879-80 (opinion of Justice Blackmun) and id. at 886-93 (dissenting opinion of Chief Justice Burger, joined by Justices Powell, Rehnquist and O'Connor) and id. at 894-85 (dissenting opinion of Justice Powell) and id. at 908-10 (dissenting opinion of Justice Rehnquist, joined by Chief Justice Burger and Justice Powell). Although all the opinions make reference to both the students' first amendment rights and the school board's legitimate socialization function, the identification of a "right to receive" ideas by Justice Brennan's opinion marks a commitment to access within the school context to ideas expressed in the larger community; the rejection of this idea by the other opinions marks a contrasting view of the school as a more protected enclave. For general discussions of the tensions between the socialization and free expression issues in schooling, see S. Arons, Compelling Belief: The Culture of American Schooling 65-74 (1983); van Geel, The Search for Constitutional Limits on Governmental Authority to Inculcate Youth, 62 TEx. L. REv. 197 (1983). 
handicapped or non-English-proficient child to become like the nonhandicapped or English-proficient child. But in a real sense, the debate over means and ends in schooling suggests that the dilemma of difference arises for all of them. It is a very similar problem in each case: does treating the different one as though he or she were not different promote sameness or confirm difference? Focusing on means and ends deepens rather than avoids this problem.

\section{B. Constraining School Power: The Difference Dilemma Recurs}

Another possible approach to the difference dilemma would seek legal constraints to curb school power and guard against the risk that the school may cause or exacerbate stigma for "different" students. Two related strategies for constraining school power arise in the contexts of bilingual and special education: (1) using other agencies (courts, school departments, state and federal agencies) to check the exercise of school power, and (2) according students and their parents procedural rights to participate in schooling decisions. Such strategies have commonly been identified as the "legalization" of school problems. ${ }^{163}$

1. Extermal Checks on School Power. The first strategy underlies the pioneering litigation in Lau, Mills, and $P A R C,{ }^{164}$ in seeking judicial supervision of school treatment of non-English speaking and handicapped children. Federal and state legislative efforts led to further external review of school decisions. Thus, the federal Justice Department and state departments of education become involved in local school treatment of special children by promulgating regulations and developing programs. This very strategy of external regulation of schools, however, puts in issue the allocation of power over educational policy and programming. Discussions of this power allocation question appear in judicial opinions about bilingual education.

In Otero, for example, the district court bolstered its denial of the plaintiffs' request for bilingual programs by express deference to the school district, which the court felt was "making a real effort." 165 The judge added that: "I could do no better, and I do not believe that a federal judge should step in where the school board and the school officials are doing their best and are doing a good job."'166

The Tenth Circuit reasoned similarly in Keyes v. School District No. 1, although it was the state legislature, as well as the local schools, that received the court's deference:

163. See Neal \& Kirp, supra note 105; Yudof, Legalization of Dispute Resolution, Distrust of Authority, and Organization Theory: Implementing Due Process for Students in the Public Schools, 1981 Wis. L. REV. 891, 894-98; see also Kirp, Proceduralism and Bureaucracy: Due Process in the School Setting, 28 STAN. L. Rev. 841, 859-76 (1976) (discussing proceduralism).

164. See supra, notes 47-48 and accompanying text (discussing Lau v. Nichols, Mills v. Board of Educ., and Pennsylvania Ass'n for Retarded Children v. Commonwealth).

165. Otero v. Mesa County Valley School Dist. No. 51, 408 F. Supp. 162, 171 (D. Colo. 1975), vacated, 568 F.2d 1312 (10th Cir. 1977).

166. Id. 
The policy of the state of Colorado is to encourage local school districts to develop bilingual skills and to assist in the transition of non-English-speaking students to English. The state legislature has established a comprehensive program for the education of children of migrant workers and has mandated the teaching of minority group history and culture in all public schools. . . . We believe that the district court's adoption [of a different plan] would unjustifiably interfere with such state and local attempts to deal with the myriad economic, social, and philosophical problems connected with the education of minority students. ${ }^{167}$

In contrast, other courts prescribed bilingual programs and reviewed the implementation of programs mandated by statute. ${ }^{168}$

Of course, both in the cases where courts approve school board decisions and those where they supplant them, the problems of constructing programs which do not create or recreate stigma for the "different" student remain. One court acknowledged the complexity:

[1]ittle could be more clear to the Court than the need . . . for special education consideration to be given to the Mexican-American students in assisting them in adjusting to those parts of their new school environment which present a cultural and linguistic shock. Equally clear, however, is the need to avoid the creation of a stigma of inferiority akin to the "badges and indicia of slavery". . . . 169

The court called upon the Anglo-American students "to adjust to their Mexican-American classmates, and to learn to understand and appreciate their different linguistic and cultural attributes." 170 But there is nothing about the court's power, compared with the school's power, that would make this adjustment less problematic. The injection of the power allocation problem - between federal and state governments, and between school boards and other entities - thus can become an issue in legal arguments, but not a replacement for the choices presented by the difference dilemma. ${ }^{171}$

167. Keyes v. School Dist. No. 1, 521 F.2d 465, 482 (10th Cir. 1975), cert. denied, 423 U.S. 1066 (1976). Special education triggers similar discussion by courts, but the structure of the EAHCA as a federal grants program with stipulations accepted by participating states frames these discussions. See, e.g., Board of Educ. v. Rowley, 458 U.S. 176, 203, 208-09 (1982).

168. Serna v. Portales Mun. Schools, 499 F.2d 1147.(10th Cir. 1974) (approving district court's detailed plan); United States v. Texas, 342 F. Supp. 24 (E.D. Tex. 1971), affd, 466 F.2d 518 (5th Cir. 1972) (detailing comprehensive plan for curriculum, instructional methodology, and staff treatment); see also Martin Luther King Jr. Elementary School Children v. Ann Arbor School Dist., 473 F. Supp. 1371 (E.D. Mich. 1979) (requiring school board to take steps to help teachers recognize students used to "Black English").

169. United States v. Texas, 342 F. Supp. at 28.

170. Id.

171. The state and federal governments, including the judiciary, legislative, and executive branches of the governments at these two levels, have become involved with bilingual and special education. Justicial decrees, administrative rules, and legislative enactments each contribute to the legal complexity in bilingual and special education programming. This governmental complexity may serve to modulate change through the existing structures of power, checking each other and balancing competing conceptions of program directions. The results divert attention from substance to the battle for control, but the legal rhetoric effectively frames policy debates in terms of a government designed to have limited power and intended to provide for orderly change. This legal structure thus resembles the central devices of the Constitution which divide power in order to create processes of decisionmaking which will prevent tyranny; thus, the Constitution contemplates a twotiered federal and state government and also separated but shared powers among the branches at each level. Protecting these structures of divided power sets in motion a rhetoric of decisionmaking such that controversial matters involve different centers of authority, contributing their perspectives to the problem and preventing any other center of authority from having the sole word. The Constitution's commitment to due process, as interpreted by the Supreme Court, similarly engages govern- 
2. Due Process Checks on School Power. The second strategy for constraining the power of the school grants students and parents procedural rights to participate in schooling decisions and to invoke review by higher state or federal authorities. This strategy notably characterizes special education. ${ }^{172}$ To some extent, this due process solution to the difference dilemma stems from a conviction that granting students and their parents opportunities for participation can reduce or obviate the risks of stigmatization in the assessment of educational needs and assignment of educational placements. According to this view, the opportunities for children and parents to check the school's decision, and simply to be acknowledged in the decisional process mitigate the danger that the school's decision will create or exacerbate stigma either by noting or failing to note the child's special needs. This procedural solution does not entirely eliminate this danger; the substance of the educational placement still will pose these risks.

To some extent, reliance on procedures, like hearings, paper submissions, and bureaucratic review, may divert the attention of teachers, parents, and policymakers from substance to procedure. In terms of the statutory framework of special education, the substantive dimensions are overshadowed by the rigor of its procedural requirements. Once a special education case progresses to a courtroom, the focus will likely emphasize procedure: the Supreme Court so prescribed in reasoning that:

[t] he congressional emphasis upon full participation of concerned parties throughout the development of the IEP, as well as the requirements that state and local plans be submitted to the Secretary for approval, demonstrates the legislative conviction that adequate compliance with the procedures prescribed would in most cases assure much if not all of what Congress wished in the way of substantive content in an IEP. ${ }^{173}$

Further, the use of procedural due process in special education may expose another version of the difference dilemma. The hearing and appeal structure introduces an adversarial mode to the educational placement decision. This can cast the child and the child's parents in the roles of outsiders or complainers-stigmatized roles-even as they seek to use the process to challenge an educational placement or to seek additional benefits. Once in the legal mode, school personnel may respond with legalistic maneuvers. ${ }^{174}$ Of course, not invoking the procedural protections could leave parents and

mental actors in processes of decisionmaking that take time, require participation by different actors, and occasion review by other officials.

172. This marks a significant point of contrast between special education, which makes the placement decision on an individualized basis, and bilingual education, which usually makes educational programming decisions on the classroom or school-wide level. This contrast may be important for many purposes, but neither route is more effective in avoiding or resolving the dilemma of difference.

173. Board of Educ. v. Rowley, 458 U.S. 176, 206 (1982). In a sense, the procedural emphasis of the governing statute converts school districts into veritable jurisdictions that promulgate rules, conduct hearings, and participate in the elaborate process of review-and this legal framework incorporates the school into the governmental structure and culture that connects local, state, and federal legal institutions.

174. See M. Budoff \& A. Orenstein, Special Education Appeals Hearings: Their Form, and the Response to Their Participants (1979); see also Kirp, Buss \& Kuriloff, supra note 46, at 128-36 (legal procedures and possibility that school personnel view parents as burden). 
child with an undesirable placement decision or with a failure by the school to undertake an assessment and select a placement. Again, inattention by the school could create a problem, but attention by the school could also create a problem for the child.

It is also possible, however, that school personnel will take advantage of the legally-mandated procedures to include parents and children in a collaborative process that builds trust over time. ${ }^{175}$ Nothing in the adoption of procedural due process, however, assures or even promotes this result. Indeed, the use of procedural due process presents a governmental norm in contrast to a trusting and caretaking norm that may otherwise dominate school personnel's conceptions of their power. The tension between these two kinds of norms can be identified as the tension between models of state power and family power. It is a tension that has occupied other efforts to check the power of schools. Schematically, legal conceptions of family power presume that the persons in power, parents, act with love, focus on the individual needs of actual persons, and depend on mutual trust and continuity. State power, in contrast, is clothed in neutrality, generality, and equal treatment regardless of individual identity, is dependent on official earmarks of authority, and is exercised with restraint and distance. As one scholar put the prevailing wisdom:

[A] government succeeds when it acts dispassionately, avoids nepotism, and treats all citizens in the same way. Conversely, a family succeeds when it acts lovingly, favors its own, and accepts each member without reservation. The one institution, then, provides justice, while the second offers acceptance. ${ }^{176}$

In short, the power exercised by the parent is presumed to be committed to the interest of the child; the parent's and child's positions toward the world are presumptively compatible and mutually beneficial. The power exercised by the state, however, is presumed to be contrary to the interests of the private individual and must be justified, limited, and bounded. Accordingly, different legal constraints apply when parents act and when the state acts; the state is constrained by the requirements of due process and equal protection, while the parents are restrained only by the state's own concern that parents love and not abuse their children.

When constraining school power is the issue, the contrast between the family and state models of power comes to the fore. In the space of two years, the Supreme Court adopted first the model of state power and then the model of parental power in constraining the nature and limits of school disciplinary power. In Goss $v$. Lopez, ${ }^{177}$ the Court concluded that when a public school seeks to discipline a child by suspension from school, constitutional rules

175. J. Handler, supra note 134, at ch. 4 (study of Madison, Wisconsin special education experience). Handler describes a collaborative decisionmaking process in which conflict is treated as an occasion for sharing information. Handler also notes that the roots of this process antedate the introduction of procedural due process by the legal initiatives in special education.

176. Stiehm, Government and the Family: Justice and Acceptance, in Changinc Images of the Family 361,362 (1979).

177. 419 U.S. 565 (1975). 
which constrain state withdrawals of entitlements apply, and therefore the suspension must be accompanied by a due process hearing. ${ }^{178}$ Here the Court viewed the school's power as state power:

The authority possessed by the State to prescribe and enforce standards of conduct in its schools, although concededly very broad, must be exercised consistently with constitutional safeguards. Among other things, the State is constrained to recognize a student's legitimate entitlement to a public education as a property interest which is protected by the Due Process Clause and which may not be taken away for misconduct without adherence to the minimum procedures required by that Clause. ${ }^{179}$

Thus the Court ordered adherence to the devices constructed by the Constitution for restraining arbitrary governmental activity and for affording individuals confronted with adverse governmental decisions with opportunities to be heard and to present a defense. ${ }^{180}$

Two years later, in Ingraham $v$. Wright, ${ }^{181}$ the Court considered the application of the due process clause to school discipline accomplished by paddling students, ${ }^{182}$ and opted for the parental conception of school power. The Court identified a common law privilege entitling public schools to use of corporal punishment, even though the Court acknowledged that the child retained the liberty interests identified in Goss. ${ }^{183}$ The Court concluded that the cost of interposing due process hearing opportunities between student and teacher outweighed the value of the use of corporal punishment unhindered by such procedures. The Court also relied on the availability of subsequent tort actions such as suing the school authorities over punishment "later found to have been excessive-not reasonably believed at the time to be necessary for the child's discipline or training . . . ."184 In so concluding, the Court effectively adopted a conception of the school's power as parental power. Parents, too, enjoy a common law privilege to physically punish their children; parents, too, need not comply with due process requirements in meting out such punishment; and parents, too, may be held liable in subsequent actions for damages where the punishment was excessive. ${ }^{185}$

178. See id. at 574 (suspension could damage child's reputation and interest in the educational benefits, so some process is due preferably before or within a reasonable time following suspension; formal adversarial hearing, however, not required).

179. Id. The Court also considered the claim that due process was required to protect the child's liberty interest and reputation.

180. The Court did suggest that this approcah can and should be made compatible with the teaching process:

further formalizing the suspension process and escalating its formality and adversary nature may not only make it too costly as a regular disciplinary tool but also destroy its effectiveness as part of the teaching process.

Id. at 583. This apparently was a large concern for the dissenters. They viewed the teacher as at times a "parent-substitute" and discipline as an educational lesson, and rejected due process guarantees as a challenge to the teacher's authority. The dissent also conceived of the classroom as "the laboratory in which this lesson of life is best learned;" thus conceiving of the means of schooling as both like the larger community and different from it. Id. at 594 .

181. 430 U.S. 651 (1977).

182. The plaintiff also raised an eighth amendment claim. Id. at 658 .

183. Id. at 676 .

184. Id. at 677 .

185. See, e.g., Gillett v. Gillett, 168 Cal. App. 2d 102, 104-07, 335 P.2d 736, 737-39 (1959) (parent civilly liable for willful tort of battery of child); RESTATEMENT (SECOND) OF TORTS $\$ \S 147$, 
The dissenters in Ingraham argued that this decision departed from the usual rules that apply to state power and state threatened deprivations of liberty in such areas as traffic regulations and prisons. ${ }^{186}$ However, it was this notion that school power is like state power in other contexts that was rejected by the majority.

Accentuated by the short time lapse between the two opinions, the disagreement over school discipline dramatizes the tension between competing concepts of what constraints there should be on power when the public schools act. ${ }^{187}$ In a sense, the model of state power, requiring due process, implies that the child is in opposition to the school and in need of the fullest set of governmental rules to guard against undue exercises of governmental power. The alternate model of parental power implies that the child is not in opposition to the school but on the same side, and governmental rules to constrain the school's power are only needed in exceptional circumstances. ${ }^{188}$

Both models conceive of the disciplinary problem as with the individual child, rather than in the relationship between the child and other children or the school staff. ${ }^{189}$ The judicial ambivalence about which conception should govern in the schools resembles the treatment of first amendment issues. Again, the special status of children as potential adults-but not yet adultsseems to complicate their legal treatment. As both like us and unlike us, children pose a discomfiting problem. We may treat them as though they were adults in designing disciplinary procedures in school, but their compulsory presence in school signals our view that they are unlike adults. At the same time, denying children the kinds of treatment adults would deserve if threatened with punishment also sits uncomfortably. The unsettled choice

150-55 (1966) (parents privileged to use reasonable force to control or educate child, but excessive punishment that is unnecessarily degrading or inflicts serious or permanent harm is not privileged); see also Salten, Statutes of Limitations in Civil Incest Suits: Preserving the Victim's Remedy, 7 Harv. Women's L.J. 189, 189-90 (1984) (discussing child's tort remedies for incest). The state may seek criminal sanctions against the abusive parent, again as a legal measure taken after the fact of parental action. See, e.g., Cal. Penal Code $\$ 273 a(2)$ (West 1970 \& Supp. 1985) (child abuse as misdemeanor when committed by any person); Cal. Welf. \& INST. Code $\$ 300$ (West Supp. 1984) (court may adjudge child to be dependent of the court if parents unwilling or incapable of providing care or control or if home unfit due to parents' abuse or neglect).

186. See 430 U.S. at 696 (White, J., dissenting). The Supreme Court split the difference in its recent decision that students do enjoy fourth amendment protections against searches by school officials, but this constitutional constraint may be satisfied by the lower standard of "reasonableness" rather than probable cause. New Jersey v. T.L.O., 53 U.S.L.W. 4083, 4086-88 (U.S. Jan. 15, 1985).

187. The same dilemma underlies the historical rise and fall of a specialized juvenile court over the course of the last 80 years. Progressive era reformers advanced parens patriae-the state as parent-as the theory to support a specialized court to deal with juvenile delinquency, child abuse and neglect, and other legal problems of children. The juvenile court was freed from due process and other constitutional constraints. Over time it became the object of resounding criticism for the abuses of power administered without such constraints, and modern reforms reintroduced procedural rights for children in juvenile court. See A. Platt, The Child Savers: The Invention of Delinquency (1969); E. Ryerson, The Best Laid Plans: America's Juvenile Court Experiment (1978).

188. The parental and state conceptions of power do not exhaust the possible forms power may take, and the development of a positive alternative to traditional state power that is not modeled on the parental role remains an important intellectual and political challenge.

189. For a contrasting view see infra note 210 and accompanying text. 
between the two conceptions makes the procedural techniques for constraining school power unlikely to solve the dilemma that disobedient children may be stigmatized among their peers if singled out for treatment with due process or stigmatized even if not accorded procedural rights. This version of the difference dilemma arises in the very legal strategy devised to curb coercive state power. Rather than seeking conceptual escapes from such dilemmas, we need to learn to live with the tension between differing concepts of power and the tension between varying responses to difference in the particular institutional settings we arrange. Thinking about such tensions differently, however, can help us learn to live with them, and it is in that spirit that the article next offers a different stance toward the difference dilemma.

\section{IV}

\section{A Different Stance Toward Difference}

The dilemma of altering the treatment of "different" children without reiterating those lines of difference cannot be avoided by focusing on the means to achieve the end of eliminating stigma, nor by seeking to check the power of schools through other institutions or due process rights. To the extent that educators and policymakers debate the relationship between means and ends, the problem of difference recurs, and it does not become more simple. Further, to the extent that bilingual and special education law and programs adopt the legal solutions of institutional checks and procedural due process, they follow a well-trodden route of legal problem solving in this culture. These solutions, however, at best forestall the difference dilemma, or move it to another point of decisionmaking or implementation. Reimmersion in the dilemma, rather than avoidance of it, can yield a more vivid understanding. In offering a reexamination, a different stance toward the difference dilemma is suggested here, not with the hope of solution, but with the hope of a more productive struggle.

\section{A. Restating the Dilemma}

The dilemma of difference is the risk of reiterating the stigma associated with assigned difference either by focusing on it or by ignoring it. Both the handicapped child and the non-English-proficient child may be stigmatized by segregated or specialized schooling based on their perceived differences from other students; yet not acknowledging their differences, and not developing programs for their needs, may make their differences continue to matter and mark them apart, in both identity and accomplishment, from other students. There are several dimensions of this dilemma, however, that contribute to its construction but have not come to light thus far.

First, the connections between difference and stigma, on the one hand, and sameness and equality on the other, must be unearthed. Indeed, equality itself can be understood as founded on the belief that people are fundamentally the same or interchangeable. As J.R. Pole has explained, constitutional notions of equality in America rest on the idea that people are equal because 
they could all take each others' places in work, intellectual exchange, or political power if they were dissociated from their contexts of family, religion, class, or race, and if they had the same opportunities and experiences. ${ }^{190}$ The problem with this concept of equality is that it makes the recognition of differences a threat to the premise behind equality. If to be equal you must be the same, then to be different is to be unequal. Indeed, as some have noted, to be different is to be deviant. ${ }^{191}$ In view of the risk that difference will mean deviance or inequality, stigmatization from identified difference is not surprising. Nor is it surprising that stigmatization results from differences which are denied or ignored (but reappears for the child perceived as different from his or her peers) or for the child who is tested as different by testing instruments designed without taking his or her characteristics into account.

This concept of equality, which links equality and sameness, and inequality and difference, is also unsatisfactory because it obscures the possibility that equality can apply to people who are different-with their differences acknowledged-and thereby obviates the need to relate across differences, rather than through the myth of interchangeability or sameness. ${ }^{192}$ At the same time, the connection between inequality and difference treats the particular categories of difference used to assign positions of equality and inequality as permanent, and, indeed, treats people as subject to categorization rather than as manifesting multitudes of characteristics. ${ }^{193}$ Categories that take the form of dichotomies-same and different, normal and handicapped, English proficient and not English proficient-especially obscure the variety and range of characteristics that more aptly describe experience.

The tendency to construct simplifying categories to make sense of the

190. J. Pole, The Pursuit of Equality in American History 293-94 (1978). An influential version of this view appears in the work of John Rawls, who posits the hypothetical original position, in which individuals abstracted from actual identities and situations choose from a position of equality the first principle of justice. See J. Rawls, A Theory of Justice 12-13 (1974); see also id. at 72-74, 123-24 (individuals to be treated as equal because luck, not desert, explains differences). The notion of the self, freed from differentiating circumstances, experiences, and involvements with others, has come under recent criticism from many quarters. See J. Elshtain, Public Man, Private WOMAN 344-45 (1981)(analysis of class rather than individualism may produce equality); M. SANDEL, Liberalism AND THE Limits OF JUSTice 171-74 (1982) (self is constituted in part by family and community membership); M. Walzer, SPheres of Justice 255-62, 271-80 (1983) (criticizing Rawls).

191. Gilligan, In a Different Voice: Women's Conceptions of Self and of Morality, 47 Harv. Educ. Rev. 481, 482 (1977); A. Lorde, Age, Race, Class and Sex: Women Redefining Difference, in Sister Outsider: ESSAYS AND SPEeches 114, 116 (1984).

192. Some recent psychological work identifies the theory of personality development as a root to this problem of equality and difference. In particular, the development of the child's sense of self in opposition to the mother has undergirded earlier studies of personality development, and supported an idea of individual identity as preoccupied with differentiation from the mother. See $\mathbf{N}$. Chodorow, The Reproduction of Mothering; Psychoanalysis and the Sociology of Gender 67-91, 99-129 (1978); Chodorow, Gender, Relation, and Difference in Psychoanlaytic Perspective, in THE Future of Difference, supra note 6, at 3, 7-8, 13; Benjamin, The Bonds of Love: Rational Violence and Erotic Domination, in The Future of Difference, supra note 6, at 41, 46-47. A promising line of inquiry would explore how the sameness supporting equality could be understood as each individual's potential to differ from others, and indeed, to differ from earlier versions of himself or herself.

193. See G. Allport, The Nature of Prejudice 19-27 (1958) (prejudice founded on categorical thinking and overgeneralization). 
complicated world may well be inevitable, ${ }^{194}$ but treating the categories as though they existed and as though they defined a person's identity and worth is another matter. Treating the individual as handicapped or English-language deficient runs the risk of assigning to that individual, as an internal limit, the category of difference that carries the message of inequality. ${ }^{195}$ This is not inevitable, for the categories of handicap and language proficiency are not the sum total of those individuals, nor are they indications of those individuals' potential or worth. Stephen Jay Gould put it this way:

Few tragedies can be more extensive than the stunting of life, few injustices deeper than the denial of opportunity to strive or even to hope, by a limit imposed from without, but falsely identified as lying within. . . . We inhabit a world of human differences and predilections, but the extrapolation of these facts to theories of rigid limits is ideology. 196

Ideology is the concern here because expressions of power, approval and disapproval are at work in the links between categories of sameness and difference and the values of equality and inequality.

A second dimension of the difference problem emerges from the following conception of equality and difference: for there to be an assignment of deviancy, it must be from the vantage point of some claimed normality; for there to be a position of inequality, there must be a contrasting position, not of equality, but of superiority. In short, the idea of difference depends on the establishment of a relationship between the one assigned the label of "different" and the one used as the counterexample. ${ }^{197}$ Once noted as a concept forged in relationship, difference no longer belongs to the one child who is called "different," but instead to the relationship between the two children under comparison. They are both different from each other, whatever the proficiencies or deficiencies used to characterize each.

Two insights can be drawn from this notion of difference as dependent upon or created by a relationship. First, there is no "normal" person or position which is itself free from being different: even as a hearing-disabled child is defined as different in terms of the child without hearing impairments, the

194. See Bruner, Art as a Mode of Knowing, in ON KNowing; Essays for The Left Hand 59, 69 (1979):

There is, perhaps, one universal truth about all forms of human cognition: the ability to deal with knowledge is hugely exceeded by the potential knowledge contained in man's environment. To cope with this diversity, man's perception, his memory, and his thought processes early become governed by strategies for protecting his limited capacities from the confusion of overloading. We tend to perceive things schematically, for example, rather than in detail, or we Id.

represent a class of diverse things by some sort of averaged 'typical instance.'

195. The flexible, individualized approach to special education embodied in the individualized education plan required by the EAHCA helps to identify the variety of deficits and strengths of each child, but the placement process used by the school may recreate categorical treatment, given limits on the school's placement options. See supra note 145 and accompanying text.

196. S. Gould, supra note 128 , at 28-29.

197. Psychological theories that locate the development of personality link the construction of a separate identity within the relationship between parents and child, which has its own dynamic of power. See E. Becker, The Birth and Death of Meaning 21-53 (1971); N. Chodorow, supra note 192; R. Kegan, The Evolving Self 76-110 (1982); Winnicott, Mirror-role of Mother and Family in Child Development, in Playing and Reality 130 (1982). 
latter child is also a "different" child, different from the hearing-impaired child. ${ }^{198}$ Both children are situated within a matrix of difference which we use to describe them; their relationship constructs what we mean by difference. Indeed, the "normal" child depends on the existence of the "different" child for the label of normal; it is the relationship, again, that constructs the difference. ${ }^{199}$

But if this point emphasizes the role of the "normal" child in the definition of difference, the second point emphasizes the participation of the "different" child in that relationship. The "different" child may actively participate in the construction and retention of the attributed difference. One educational researcher described an example of this. Rosa is a child whose native language is Spanish and who is at the bottom of her English reading group in first grade. After filming Rosa's interaction with her teacher and classmates, the researcher concluded that Rosa

conspires with the teacher in not getting a turn to read. Although she often requests a turn to read, she does so in unusual ways: she checks to see what pages the other children are reading, turns to a different page, and then calls for a turn; she waits for the teacher to start to call on another child and then quickly calls for a turn; or she calls for a turn while looking away from the teacher. . . . The teacher organizes the turn taking in the group randomly, so that Rosa never has to be asked to read as she would if the teacher called on children in order around the table . . . Rosa spends her time avoiding a turn to read. 200

The researcher concluded that

\begin{abstract}
Rosa's actions make sense when one considers her beginning reading skills, the competitive pressures of the classroom, and the teacher's organizational methods. The teacher's behavior makes sense given her task-teaching a child to read while keeping a whole roomful of children busy at other tasks. Together, they behave sensibly in relation to each other and appear to be doing their best. But together they do not achieve trusting relations. Rosa and the teacher do not understand each other's behavior as directed to the best interest of what they are trying to do together, namely, to get Rosa organized for learning how to read. ${ }^{201}$
\end{abstract}

This may be an extreme case of a child's collusion in the construction of difference; it suggests her belief that exposing her difference by seeking a reading turn would be more painful than retaining that difference.

The difference dilemma, then, depends on the relationship constructed to define "different" and "normal," and on the association of equality with sameness and of deviance with difference. These conceptual associations are in conflict with the mission of schools, which aim to help all students, and which carry an ethos of possibility and future equality for all. As noted in the discussion of first amendment issues in the schools, the commitment to con-

198. This is a separate point from the real possibility that this child has still other impairments or strengths not relevant to the question of hearing.

199. Hegel's master/slave discussion elaborates this point: the master needs the slave for the master to be recognized as master, and therefore constructs a relationship of dominance and submission rather than negating or destroying the slave. G. Hegel, Phenomenology of Spirit 141-50 (1952).

200. McDermott, Social Relations as Contexts for Learning in School, in Knowledce and Values in Social and Educational Research 252, 257-58 (E. Bredo \& W. Feinberg eds. 1982).

201. Id. 
sider all children as potential participants in the adult community, however far from that they currently may seem, challenges the association of the child's difference from the adult with deviance, and urges efforts to prepare the child for adulthood. How can this set of values in schooling survive the difference dilemma? Other than describing as vividly as possible the nature of this dilemma, what strategies for dealing with it might reduce the risks of recreating stigma by either ignoring or focusing upon it?

\section{B. Toward a Different Stance}

Understanding that stigma is a likely risk so long as "difference" means "deviance" rather than equality exposes the following problem: how can equality be achieved given the acknowledgment of difference? In a sense, this is the problem buried within the difference dilemma: the fear of reiterating difference, whether by acknowledgment or nonacknowledgement, arises as long as difference carries stigma and precludes equality. Locating difference in the relationship rather than in the person or group called "different" may permit a new stance toward the problem of stigma. Focusing on the relationship or matrix in which difference is created may offer people the chance to acknowledge difference and not locate it in another who then is unequal, but instead in the relationship used to define that "difference." More simply, this set of rather abstract arguments can justify looking at the problem of difference as a shared problem of relationships and contexts-a problem requiring a collaborative solution to change the very matrix of difference. The goal is not to pretend that differences are not noticed, nor that all students are the same, nor to focus on the students who are "different" as the problem, but instead to identify as the problem the shared context in which difference appears. The dilemma of difference will not disappear, but struggles with it may prove more fruitful from this shifted stance toward the shared problem of difference. ${ }^{202}$

\section{Some Examples and Some Continuing Problems}

1. Parents of Special Education Students. An initial example of a school system's shift in stance on the issue of difference appears in Joel Handler's study of special education in Madison, Wisconsin. ${ }^{203}$ The focus in this study is on the parents of students in special education, rather than on the students themselves. Parents of children with special needs can be made to feel different from other parents, at odds with the school and obstacles in the

202. Who shares the power to make decisions about educational programs which deal with difference is bound to be an issue. If decisional power is held only by people who assign the difference problem to others, who have no decisional power, a shift in stance is unlikely. This article does not address who should be included in the planning decisions or in the definitions of the problems to be addressed by those decisions, but it may be important to include in educational planning teachers and administrators, parents, and students who "have" the characteristics of "difference" to give the planners themselves the chance to grapple with their own involvement in the construction of difference.

203. J. HANDLER, supra note 134, ch. 4. 
school's response to their children, and stigmatized for having failed or otherwise earned blame. But parents with children in the Madison program describe a different experience. Handler explains that the culture and ideology of the Madison program made special education part of general education, and special education services part of a continuum of all educational services. ${ }^{204}$ Also, because all parents are treated as an important part of regular education, parents whose children receive special education services are also considered to have important roles in their children's education. As one school administrator reported, " 'Parents with handicapped children are made more like other parents rather than being differentiated. Parents and kids build their identity first as members of the school district rather than as a handicapped child or a parent of a handicapped child.' "205 By including parents early on in the planning process for their child's special education program, the parents develop a stake in the outcome. ${ }^{206}$ Even with the framework of due process rights and potential adversarial hearings, the school's stance brings the parents on the same side of the problem as the school; both are part of the solution.

However, there are real shortcomings with this approach: parents may be co-opted or moved to a position of passivity in the face of the school's attitude and expertise. ${ }^{207}$ Further, community attitudes stigmatizing students may well remain untouched. Again, this example concerns only the treatment of parents of students in special education; when the students themselves are involved, a shift in stance must somehow locate all the students on the same side of the problem, as part of the solution.

2. A Classroom and a Hearing-Impaired Student. Imagine a teacher facing a mainstream second grade class which included a severely hearing-impaired child like Amy Rowley. Initially, the choices seem to be to obtain a full-time sign language interpreter in the mainstream classroom or simply to include Amy in the regular classroom instruction, supplemented by some separate instruction for her during part of the day. ${ }^{208}$ Both of these approaches treat the problem of difference as located in the hearing-impaired child, and equality as conditioned on sameness. Either a special instructor has to be secured just for her, or else she is to be treated for the most part just like any other student. Any special treatment again singles her out, reiterating the assignment of difference to Amy. A different stance toward the problem would conceive of all the students as part of the problem. The individual teacher would ask herself what approach to the problem would work to the educational benefit of every student in the classroom.

204. Id. at 21 .

205. Id. at 22. How children actually feel is not examined in detail in the study.

206. Id. at 36 .

207. Id. at 63-64, 79 .

208. See supra notes $135-43$ and accompanying text (discussing Board of Educ. v. Rowley, 458 U.S. $176(1982))$. Another option would be to send the child to a class specially for the hearingimpaired. Cost factors may, of course, operate quite powerfully in the assessment of the alternatives. 
One approach she might take would be to instruct all the students in sign language, and run the class in both spoken and sign language simultaneously. This approach would engage all the students in the difficult and educational issues of how to communicate across traditional lines of difference, how to struggle with the difficulties of translation, how to understand all language as arrangements of signs, how to employ group action to improve the situation of an individual, and how to turn the authority of the teacher into the compassion of the group. This approach affords a different stance toward the dilemma of difference: making the hearing-impaired child's difference no longer signify stigma or isolation while still responding to that difference as an issue for the entire community. It also could bring the means of education close to the ends of individual and community responsibility for problem solving and enhanced individual knowledge. This solution also involves the exercise of school power in a way which resembles love while achieving the legal demands of equal treatment.

Again, this example is hardly a model for all classrooms, or even for many. There is no promise that the non-hearing-impaired students will happily respond to this approach, or that their parents will not reject it as a waste of their children's time. ${ }^{209}$ Moreover, an analogous approach to bilingual education, such as having each child learn the languages other children use at home, would be unwieldy and likely to provoke massive opposition. Nonetheless, the learning value of the experience for all the children could be defended. Struggling to be understood in a language that feels foreign would provide an important lesson to each child about their shared problems and about the abilities and disabilities of each student. Once located, the problem of difference in this shared context could alleviate the risk of stigma, while deepening each child's sense of what it means to live in a social world.

An analogous stance toward the problem of the unmanageable child already contributes to educational programs. The unmanageable child can disrupt an entire class, but rather than simply placing the child in isolation outside the classroom, one alternative is to pair two teachers who may send an unmanageable child to each other's classroom. Significantly, the procedure is introduced to the entire class in a group discussion so that the defiant child is not singled out, and when that child returns to the original classroom,

the excluding teacher reviews the situation with her class, emphasizing the reasons behind the relevant rules and alternative ways in which the excluded child might have acted. Whenever possible her remarks are channeled into a group discussion that can be used to marshal the support of the class in helping the excluded child. Once children have expressed their expected bitterness toward the defiant child in such discussions, the teacher can elicit more sympathetic interest from them in helping him,

209. The identification of many different kinds of special needs expressed by other students could complicate the program considerably. How would a blind or a cerebral palsied student participate? Yet these and other practical problems could be worked out within a specific school context. After this article was written, it came to the author's attention that a local school responded to the enrollment of a hearing-impaired child with sign language instruction for classmates, much like the suggestion made here. Telephone communication with Clare Dalton (Dec. 16, 1984) (describing Cambridge Friends School). 
especially when she points out that she needs help from the class in teaching the excluded child to follow class rules. 210

Here, too, the entire class is included in the problem as well as another class. The issue of discipline itself becomes an educational process involving all of the students. The problem, then, is not located solely in the "different" child, but in the demands of the society of the classroom for managing behavior and following rules.

3. Schooling, Not Schools. At a more macro level, another kind of inquiry would pursue the features of schooling that could be altered to ease the dilemma of difference. One such feature is the confinement of the schooling process to a given school setting. ${ }^{211}$ This feature exacerbates the difference dilemma by making the removal of any individual child from the established school setting carry stigmatizing and isolating consequences. Because that child is treated differently from other children, the association of inequality follows, and the "difference" is deposited on the child rather than on the school setting itself.

Consider as an alternative the creation of supplemental schooling environments so that students spend different days or portions of different days in different settings, with different mixes of children and teachers. Experiments of this nature may be costly or difficult to administer. The idea is worth some attention, however, because at least it provides a different stance toward the difference dilemma in bilingual and special education. Making "pull-outs" and movement in and out of the standard classroom the norm rather than the exception could cut the link between stigmatizing difference and special educational programming. No student or subset of students would be considered "different" simply because of classes or programs outside the regular classroom; the regular classroom itself would cease to be the "norm" against which "difference" is established. Students would undoubtedly take little time in establishing who is leaving the classroom for an enrichment science class, and who is leaving for remedial speech therapy. ${ }^{212}$ Nonetheless, a real mix of special classes could modulate the implicit hierarchy of such extra classes, and diminish the implication that difference resides in the unusual student rather than in all the students.

One strategy would pull each student out for instruction in a language in which he or she is not proficient-and make use of that language instruction in the mainstream social studies class for those studying Spanish as well as those studying English. This could diffuse the status issue associated with each language problem, and enrich the social studies class as well. Engaging

210. S. Sarason, The Culture of the School and the Problem of Change 138 (1971) (quoting member of Yale Psycho-Educational Clinic who described procedure implemented in an inner-city school).

211. But see L. Cremin, American Education: The National Experience 1783-1876 163-71 (1980) (education historically conducted in settings outside of schools: families, churches, job settings).

212. Cf. S. Lightfoot, supra note 133, at 358 (students sensitive to curricular divisions as expressions of class hierarchy). 
in multiple educational strategies could avoid the elevation of any given means to the ends of schooling. Diffusing power through different relationships within the life of the school, rather than through different governmental power centers directing school programs, could provide openings for more individualized attention, and create trusting relationships between adults and students.

\section{$\mathrm{V}$ \\ Conclusion}

The dilemma of difference is unlikely to disappear in the near future. The patterns of debate and legal response to the dilemma fail to uncover the ways in which difference is created in relationships and inequality is associated with difference. The choice between programs that create enclaves of bilingual and special education and programs that create a microcosm of the larger community in each classroom does not offer a way out of the dilemma. Developing methods to check school power through institutional review or through due process similarly does not resolve the problem. This article has tried to describe the hold that the difference dilemma seems to have in legal and policy debates over bilingual and special education. In part, this explicit and at times anecdotal depiction of the dilemma is intended to make it more apparent, and less likely to catch us unaware.

The article has also suggested an alternate stance toward the problem. This different stance locates the problem of difference in the relationships that define it, and the problem of stigma in the association of sameness with equality and of difference with inequality. This stance bears a resemblance to the new stances developed by philosophers of science and social science toward the problem of knowledge. There, too, the problem of difference has been highlighted, but in the form of the distinction between the observer and the observed. The scientist-observer, according to recent theorists, is not separate nor totally different from the subject under observation, but participates in the creation of knowledge and in the construction of what is to be known. ${ }^{213}$ Similar ideas animate developments in psychology. Not only is the relationship between the therapist and the client a focus for psychotherapy, each individual's construction of relationships to her or his social world and the interactions that occur is attended to by psychology. The development of

213. R. Bernstein, Beyond Objectivism and Relativism: Science, Hermeneutics, and Praxis 71-108 (1983) (role of choice and judgment in scientific knowledge, challenging distinction between objectivity and relativism); S. LightFoot, supra note 133, at 376-78 (researcher using portraiture exchanges and engages with the subject, and directly touches them); M. Polanyi, Personal KNowledge: Towards a Post-Critical Philosophy (1958) (tacit participation of observer in knowledge); C. Wilson, The New Existentialism 39, 49 (1966) (phenomenology rejects positivism's assumption that the mind can be taken for granted in the study of the world); Flax, Mother-Daughter Relationships: Psychodynamics, Politics, and Philosophy, in The Future of Difference 20, 21 (1980) (criticizing view from "empiricism and many forms of rationalism, the subject is considered totally different, substance and process, from the object"); Taylor, Interpretation and the Science of Man, in KNOWLEDGE AND Values in Social and Educational Research 153, $177-78$ (1982) (subjective meanings and shared meanings constitute study, not just brute facts). 
categories to explain mental disturbances is linked to the development of categories to explain "normal" development, and the potential for both normal and abnormal development, for anyone, is the basic message. ${ }^{214}$

Each of these intellectual moves may carry real consequences for moral conduct, for they each speak to the problem of how one person should approach another. As Walter Kaufman put it:

Nothing Freud has done, and little that anyone else has done, is more relevant to ethics than his success in breaking down the wall between the normal and abnormal, the respectable and the criminal, the good and the evil. Freud gave, as it were, a new answer to the gospel query, "Who is my neighbor?" The mentally troubled, depressed, hysterical, and insane are not possessed by the devil but essentially "as thyself." 215

Perhaps these intellectual developments can sustain practical efforts not to escape the dilemma of difference, but to locate it as the context for all children, regardless of how we adults may describe their impairments or strengths, cultural backgrounds or language proficiencies. Perhaps then we can hope to act on the conflicting but sincere commitments to the children involved.

214. See M. Edelson, The Idea of a Mental Illness 105-36 (1971) (shared human symbolic processes the subject of therapy in relationship between patient and therapist); $R$. KEGAN, supra note 197, at 76-110 (the construction of the self in relationship to others); S. Minuchin, Families and Family Therapy 4-15 (1974) (interaction between individual and social context is site of pathology and subject of therapy); Freud, Psychoanalysis, in Character and Culture 230-52 (P. Rieff ed. 1963) (1922 essay describing elements of psychoanalysis).

215. W. Kaufman, From Shakespeare to Existentialism: An Original Study 337 (1960). 
